HARMFUL ALGAL BLOOM (HAB) COMMUNITIES AND CO-OCCURRING SPECIES

IN RELATION TO NEAR SHORE OCEAN DYNAMICS

IN SAN LUIS BAY, CALIFORNIA

\begin{abstract}
A Thesis
presented to

the Faculty of California Polytechnic State University,

San Luis Obispo
\end{abstract}

In Partial Fulfillment

of the Requirements for the Degree

Master of Science in Biological Sciences

by

Samuel Christopher Rankin

May 2011 
(C) 2011

Samuel Christopher Rankin ALL RIGHTS RESERVED

ii 
TITLE:

AUTHOR:

DATE SUBMITTED:

COMMITTEE CHAIR:

COMMITTEE MEMBER:

COMMITTEE MEMBER: Scott Steinmaus, Ph.D.

May 2011

Mark Moline, Ph.D.
HARMFUL ALGAL BLOOM (HAB) COMMUNITIES AND CO-OCCURRING SPECIES IN RELATION TO NEAR SHORE OCEAN DYNAMICS IN SAN LUIS BAY, CALIFORNIA

Samuel Christopher Rankin

Christopher Kitts, Ph.D., Biological Sciences Department Chair 
ABSTRACT

\title{
HARMFUL ALGAL BLOOM (HAB) COMMUNITIES AND CO-OCCURRING SPECIES IN RELATION TO NEAR SHORE OCEAN DYNAMICS IN SAN LUIS BAY, CALIFORNIA
}

\author{
Samuel Christopher Rankin
}

The occurrence of phytoplankton taxa, with special focus on harmful algal bloom (HAB) taxa, was monitored for one year off the central coast of California to examine both their cooccurrence and physical and chemical variables influencing their temporal patterns. Bi-weekly samples were taken from October 6, 2008 to October 5, 2009 in San Luis Obispo Bay, CA. Canonical correspondence analysis (CCA) of weekly samples indicated that $46.1 \%$ of the variability in species abundance was explained by the variables in the model, higher than previous reports. Cluster analysis divided phytoplankton communities into HAB and non-HAB groups of species, while shared distribution analysis identified specific co-occurring species of HABs. The HAB dinoflagellate group consisted exclusively of HAB taxa, including Cochlodinium polykrikoides Margalef, Dinophysis acuminata Claparède \& Lachmann, and Alexandrium spp., and was correlated with a homogeneous water column and high nitrate concentration during the fall and winter seasons. The domoic acid producing diatoms Pseudonitzschia seriata (Cleve) H. Peragallo complex and Pseudo-nitzschia delicatissima (Cleve) Heiden complex grouped with several other non-HAB diatoms, and were correlated with warm, thermally stratified waters of the summer season. These results contradict the classic diatom / dinoflagellate succession theory and suggest that event-scale processes influencing water column stability within seasons may influence the distribution of HAB species in near shore upwelling dominated regions.

Keywords: phytoplankton, harmful algal bloom (HAB), communities, co-occurring species, canonical correspondence analysis (CCA), diatoms, dinoflagellates, coastal, California 


\section{ACKNOWLEDGMENTS}

This work was funded in part by the NOAA to Cal Poly, San Luis Obispo through the Southern California Coastal Ocean Observation System (SCCOOS). Thanks to my committee chair, Mark Moline, for guidance throughout, and to committee members, Chris Kitts and Scott Steinmaus, for additional guidance. Thanks to Jo Anna Goodman and Mark Brzezinski at the Marine Science Institute of UC Santa Barbara for nutrient analysis of samples. Thanks to Erica Seubert and Dave Caron of USC for domoic acid analysis of samples. Special thanks to Brian Zelenke of Cal Poly’s Center for Coastal Marine Science for assisting with data acquisition from the Cal Poly Pier instrumentation. Thanks to additional members of the Center for Coastal Marine Science for help and support, including Ian Robbins, Anniken Lydon, Johanna Weston, Jason Felton, and Carol Boland. 


\section{TABLE OF CONTENTS}

\section{Page}

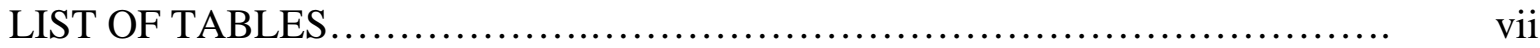

LIST OF FIGURES …......................................................... viii

\section{CHAPTER}

I. INTRODUCTION .......................................................

II. METHODS ............................................................ 3

Data Collection.................................................... 3

Statistical Analysis............................................. 5

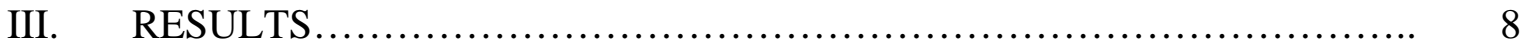

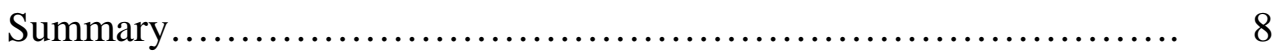

Canoncial Correspondence Analysis (CCA) ......................... 11

Co-occurring Species........................................... 14

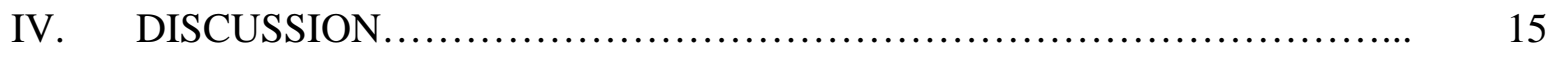

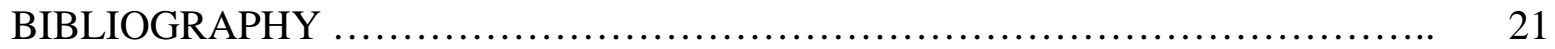
APPENDICES

Table S1...................................................... 39 


\section{LIST OF TABLES}

Table

Page

1. Taxa occurring in at least $10 \%$ of weekly samples $(\mathrm{N}=51)$ sorted by abundance

2. Forward selection of variables sorted by $\lambda_{\mathrm{A}}$, the marginal significance of each variable by itself. Variables with p values $>0.05$ were deselected from analysis (shaded).

3. Clustering on species scores for the four canonical axes. HABs taxa are shaded..................................................................

4. Variance Partitioning of Physical and Chemical Variables.

5. Co-occurring species with at least 50\% Sorensen similarity (presence/absence) based on semi-weekly sampling.................... 


\section{LIST OF FIGURES}

Figure

Page

1. Time series of some of the variables used in the canonical correspondence analysis (CCA). Sampling period is Oct 6, 2008 to Oct 5, 2009 unless otherwise noted. (a) Twice-weekly temperature time series taken from the Cal Poly Pier's underwater line (UWL) at 1.5 m mean low low water level (MLLW). (b) Twice-weekly salinity time series created with surface measurements from the Cal Poly Pier's vertical profiler, and measurements from Cal Poly Pier's UWL at 1.5 m MLLW. Time series ends Sept 7, 2009. (c) Twice-weekly time series of difference between temperature measurements taken at 1.5m MLLW and 7.5 m MLLW from Cal Poly Pier's UWL. (d) Weekly nitrate, ammonia, and DA time series from surface water samples.

2. Twice-weekly total cell concentration (solid line) plotted over stacked histogram of the percent of total of the eight most abundant taxa............

3. (a) Weekly chlorophyll $a$ time series taken from surface water samples. (b) Weekly log diatom and log dinoflagellate time series calculated from surface water cell concentrations. (c) Area plot of weekly percent diatoms and percent dinoflagellates with percent HAB taxa histogram superimposed

4. Canonical correspondence analysis (CCA) biplots in two-dimensional CCA space defined by Axes 1 and 2. Variables are displayed as vectors, the lengths and directions of which are dependent on their scores in the first two axes. The strength of variables associated with sample dates or species can be seen by the perpendicular projection of the biplot score onto the arrow or extension of the arrow in either the positive or negative direction.

(a) Weekly sample dates plotted in CCA space and coded by season.

(b) Most common species which occurred in at least $10 \%$ of weekly samples plotted in CCA space. Color coded groups were determined by cluster analysis of the species CCA biplot scores (Table 2).... 
Introduction

A phytoplankton bloom occurs when a community experiences a large increase in population growth of a few species (often only one) due to favorable conditions specific to those species (Graham et al. 2009). A small percentage of phytoplankton species may form harmful algal blooms (HABs) which can result in discolored water (i.e. red tide), foam from accumulation of excessive photosynthate, and oxygen depletion of waters where the bloom occurs. In addition some HABs species produce toxins which can accumulate in the food chain causing sickness of marine wildlife, fisheries closures due to public health concerns, and economic losses (Horner et al. 1997; Sellner et al. 2003). The frequency of HABs in coastal areas appears to be increasing, potentially due to anthropogenic eutrophication (Kudela et al. 2008), but this could also be partly due to heightened awareness and monitoring of these events in the last century. Nevertheless, understanding the conditions which cause HABs is important for managing coastal resources and protecting the health of marine wildlife and humans.

Several toxin-producing HAB taxa occur on the West Coast of North America. Five species of the diatom genus Pseudo-nitzschia (P. australis, P. multiseries, $P$.

pseudodelicatissima, $P$. pungens, and $P$. seriata) are known to produce domoic acid (DA) which causes sickness and death in pelicans, sea lions, and other marine mammals (Jester et al. 2009; Horner et al. 1997). Six species of the dinoflagellate genus Alexandrium produce paralytic shellfish poisoning (PSP) toxins which have caused human deaths through shellfish consumption (Jester et al. 2009). Four species of the dinoflagellate genus Dinophysis are known to produce diarrhetic shellfish poison (DSP). Red tide dinoflagellates of the West Coast which do not produce toxins but may cause fish mortalities due to anoxic conditions include Cochlodinium 
spp., Ceratium spp., Gymnodinium spp , Lingulodinium polyedrum, Noctiluca scintillans, Prorocentrum micans, and Protoperidinium spp. (Horner et al. 1997; Curtiss et al. 2008).

The formation of regularly occurring phytoplankton communities can be attributed to the presence of certain water masses with chemical and biological characteristics to which they are adapted (Venrick 1971; Vila \& Maso 2005). Change in community structure can have important implications in food web dynamics and nutrient cycling (Graham et al. 2009), and can be brought about by succession and/or advection (Garrison 1979; Smayda 1980). Two well-studied communities are defined as either diatom-dominated or dinoflagellate-dominated (Briand 1976; Margalef 1978; Garrison 1979; Delmas et al. 1992). Margalef (1978) described community changes in temperate regions from diatom-dominated to dinoflagellate-dominated based on seasonal changes in water characteristics. In this construct, diatom growth is favorable during high nutrient, turbulent conditions of spring-time upwelling periods. Low-nutrient stratified conditions, which follow in summer and fall, favor a shift to dinoflagellates (Margalef 1978) which are adapted by their ability to diurnally migrate through nutriclines (Schofield et al. 2006). This transition could be caused by advection of communities by currents (Delmas et al. 1992; Magda \& Masó 2005), or by a natural community succession in response to seasonal change (Figueiras et al. 1994). In addition, red tide species may favor transitory conditions where stratified waters meet an upwelling zone (Margalef 1978).

As with other phytoplankton species, HABs species manifest themselves as part of an assemblage of co-occurring species and often these assemblages are recurring, such that a bloom of a specific species may be predicted if other members of the community are observed and water conditions are favorable (Figueiras et al. 2006). Additionally, long term changes in phytoplankton community structure and their underlying driving mechanisms (i.e. physical and 
chemical environment) can lead to changes in algal toxins, which can impact the food web and seasonal wildlife (Jester et al. 2009). In this paper, we investigate changes in the phytoplankton community structure, environmental variables, and toxin levels over one year in San Luis Bay, CA, a HABs susceptible area on California's central coast, in order to explain the environmental influences of community-level changes with special emphasis on species groupings and cooccurring species of potentially HAB forming members.

Methods

\section{Data Collection}

From the Cal Poly Pier in San Luis Obispo Bay, CA, one liter surface samples were taken twice weekly on regular days from October 5, 2008 to October 6, 2009. Sample times were as consistent as possible, with the majority of samples ( $>80 \%)$ taken between the hours of 11:00am and 4:00pm local time. A $90 \mathrm{ml}$ aliquot was preserved in 4\% formaldehyde in a French square bottle, $25 \mathrm{ml}$ of which were allowed to settle for 24 hours in a settling chamber (Utermöhl 1931). Quantitative cell counts were performed using an inverted light microscope (Olympus, Center Valley, PA, USA) at 200x, and species were identified according to Horner (2002), Hasle \& Syvertson (1997), and Steidinger \& Tangen (1997). All cells were identified to species, and if this was not possible, then to genus. Pseudo-nitzschia specimens were grouped into one of two complexes since species identification by LM is difficult and requires close examination of frustules by EM. The Pseudo-nitzschia seriata complex is characterized by cells wider than $3 \mu \mathrm{m}$ with $1 / 4$ to $1 / 3$ overlap between chained cells, and includes $P$. australis, $P$. multiseries, $P$. fraudulenta, and P. seriata. The Pseudo-nitzschia delicatissima complex is characterized by long narrow cells less than $3 \mu$ m wide with 1/8 to 1/9 overlap between chained cells, and 
includes P. pseudodelicatissima and P. delicatissima (Horner 2002; Hasle \& Syvertson 1997). Ten random fields of view were used to estimate cell concentrations, unless cells were scarce, then 20 fields of view were used. The cell concentration detection limits based on sub-sampling were 1389 cells/L or 2778 cells/L depending on the number of fields of view used, and one half of the lower limit (694) was used in place of zeros for all multivariate analyses described below.

Samples for chlorophyll a (chl $a$ ), nutrients, and DA analysis were collected once per week, coincident with one of the samplings detailed above. For chl $a$, four $100 \mathrm{ml}$ surface water replicates were filtered onsite with $25 \mathrm{~mm}$ glass fiber filters. Filters were stored in cryovials, frozen at $-4^{\circ} \mathrm{F}$ onsite, and transported for immediate processing at California Polytechnic State University, San Luis Obispo, CA, or were kept frozen at $-80^{\circ} \mathrm{F}$ until analyzed at a later time. Filters were extracted overnight with 90\% acetone and analyzed for chl $a$ using a Turner 10-AU Fluorometer (Turner Designs, Sunnyvale, CA, USA). Corrected chl $a$ and phaeophytin values were calculated according to EPA method 445.

The sample for nutrient analysis was collected and filtered through a GF/F filter for a 40 $\mathrm{ml}$ sample. These samples were stored in glass scintillation vials and frozen at $-4^{\circ} \mathrm{F}$ until shipped with dry ice (approximately monthly) to University of California Santa Barbara’s Marine Science Institute where they were analyzed for nitrate and ammonia by flow injection techniques (Johnson et al. 1985) on a QuickChem 8000 analyzer (Lachat Instruments, Loveland, CO, USA). Nitrite and phosphate were also quantified, but it was determined that there were sporadic problems during analysis resulting in erroneous values and were not used in this study.

Two $200 \mathrm{ml}$ aliquots were filtered through a GF/F filter for DA analysis. These samples were stored in cryovials and frozen at $-4^{\circ} \mathrm{F}$ until shipped with dry ice (approximately monthly) to University of Southern California's Marine Biology Laboratory in Los Angeles, CA for analysis 
using the Domoic Acid Enzyme-Linked ImmunoAssay (ELISA) (Mercury Science, Durham, NC, USA) as described in Litaker et al. (2008).

The Cal Poly Pier is equipped with an instrumented underwater line (Aanderaa Data Instruments, Bergen, Norway) with Aanderaa 3231 conductivity-temperature-depth (CTD) sensors located at $1.5 \mathrm{~m}$ and $7.5 \mathrm{~m}$ below the mean low-low water level (MLLW). The $1.5 \mathrm{~m}$ MLLW measurements were used to estimate surface conditions, and the difference between the 1.5m MLLW and 7.5m MLLW was used to estimate thermal stratification in the water column (total water depth is $11 \mathrm{~m}$ ). Only data for water sampling days were used for this study.

The Cal Poly pier is also equipped with an autonomous vertical profiler (California Polytechnic State University, San Luis Obispo, CA, USA), which collected temperature and conductivity measurements from the full water column every 30 minutes using a Seabird 37 SIP CTD (Seabird Electronics, Bellevue, WA, USA). Surface water measurements from the profiler were used on those days when sampling occurred.

\section{Statistical Analysis}

Multivariate analyses of species abundance and environmental variable matrices were carried out using Canoco for Windows v4.53 (Biometris Plant Research International, Wageningen, Netherlands) according to Ter Braak \& Šmilauer (2002), and PC Ord v5.31(MJM Software Design, Gleneden Beach, OR, USA) according to McCune \& Grace (2002). One sample date in late December was not included due to missed sampling, and the last four weekly samples were not included in the analysis due to lack of concurrent data. The resulting data set used in this study consisted of 48 sample dates in the weekly matrix (October 6, 2008 to September 7, 2009). Cell counts were log transformed to remove bias due to biomass, and only species occurring in $10 \%$ or more of the sample days were included in the analysis, resulting in 
19 species for the weekly abundance matrix. Variables analyzed with species abundance were temperature, salinity, thermal stratification, percent HABs species, Shannon's diversity index, log total diatoms, log total dinoflagellates, chl $a$, nitrate, ammonia, and DA. Thermal stratification of the water column was estimated by the temperature difference between the two underwater line sensors. HABs species were defined as species of special concern in California which are monitored by the Southern California Coastal Ocean Observations System (SCCOOS; see sccoos.org), which include Pseudo-nitzschia spp., Alexandrium spp., Dinophysis spp., Prorocentrum spp., Lingulodinium polyedrum, Akashiwo sanguinea, and Cochlodinium spp.

A preliminary de-trended correspondence analysis (DCA) was performed using PC Ord in order to test the unimodal nature of the data which is necessary for canonical correspondence analysis (CCA) (Leps \& Smilauer 2003). DCA analysis results indicated that the variable responses were unimodal based on segment lengths exceeding four standard deviations, and that the data were appropriate for CCA. Weighted correlations of all variables were reviewed to ensure that multi-colinearity of redundant variables would not influence results. If two variables had a correlation value above 0.700 , the most ecologically important variable was selected and the other removed from analysis. For example, species richness and species diversity (Shannon index) were correlated higher than 0.700 , and so species richness was removed. The variables selected for analysis all have pair-wise correlations less than 0.700 . Multivariate outlier analysis using PC Ord was carried out to test the effects of outliers. Sample units with Sorensen distances greater than two standard deviations from the mean were removed from species and variable matrices prior to multivariate analysis. Since the explained variance in the original analysis (43.7\%) was similar to the explained variance with outliers removed (43.9\%), the outliers did not appear to have a large influence on the analysis, and therefore were included. 
Canonical correspondence analysis (CCA) is an ordination method which extracts synthetic axes from species abundance and environmental or temporal gradients explaining most of the variation in species composition (Leps \& Smilauer 2003). Axes are combinations of multiple variables, with the first two axes explaining the most variance in community composition representing two dimensional space. The biplot scores of species and samples are rendered in this space in relation to variable vectors to elucidate how environmental or temporal variations are related to species composition (McCune \& Grace 2002). CCA of species abundance and temporal variable matrices in this study was carried out using biplot scaling focused on inter-species distances. A manual forward selection procedure using Monte Carlo permutations was carried out to test the marginal significance of each variable in explaining variance in the species abundance (Leps \& Smilauer 2003). Variables with less than 95\% confidence $(p>0.05)$ were removed from the analysis and the remaining variables were subjected to another forward selection. This procedure included three forward selection steps, with three variables (Shannon index, Salinity, and ammonia) removed after the first run, and one variable (chl $a$ ) removed after the second run. In the third run, all remaining variables were significant and were therefore included in the final CCA.

Multiple CCAs were then carried out to partition the variance between the physical and chemical components of the analysis to quantify the weight each group of variables carried in explaining species abundance (Legendre 2007). All physical and chemical variables including those removed during the forward selection procedure were included in this analysis. A total of five analyses were performed in order to account for covariance between the two sets of variables. Physical variables analyzed were temperature, salinity, and stratification. Chemical variables analyzed were nitrate and ammonia. 
Groups of phytoplankton species with similar environmental variable responses were identified by clustering of CCA species biplot scores using PC Ord. Groups were identified by hierarchical, agglomerative cluster analysis (Euclidean distances, Ward's linkage) on the CCA species biplot scores, with dendrogram scaling using Wishart's objective function. Dendrograms were pruned to the four most unique phytoplankton groups.

In order to identify specific co-occurring species of HABs regardless of abundance and at a higher sampling resolution, a Sorensen distance matrix of presence/absence data was used for species which occurred in at least $10 \%$ of the semi-weekly abundance data $(\mathrm{N}=20)$.

Presence/absence was used to eliminate bias of co-occurrence during high biomass events and to account for shared distribution over the entire sample period. Co-occurring species were identified as having a Sorensen similarity (shared occurrence) of 50\% or greater.

\section{Results}

Summary

Time series of surface temperatures showed an expected seasonal trend with a general decline from the beginning of the sample period until May 2009, then an increasing trend continuing to the end of the sample period. This larger trend was characterized by frequent even-scale changes of up to $3^{\circ} \mathrm{C}$ over a given week (Figure 1a). Corresponding salinities showed a mean value of 33.3 PSU with episodic changes due to local rainfall, upwelling, and the poleward flow of lower salinities during relaxation events (Melton et al. 2009) (Figure 1b). The thermal stratification index showed mixed conditions in the water column from October 2008 through February 2009 (Figure 1c). Increasing stratification began in March and continued with large fluctuations in water column instability, with stratification peaking in July, then declining 
as fall approached at the end of the sample period (Figure 1c). Corresponding to the stratification, nutrients showed highest concentrations in winter and lowest during the primary growing season from May-July 2009 (Figure 1d).

A total of 74 separate species were identified in the twice-weekly surface sampling (Table S1). The eight most abundant taxa made up 93\% of the total cell counts, consisting of the chain-forming diatoms Leptocylindrus danicus (Cleve), Chaetoceros spp., Skeletonema costatum (Greville) Cleve, Pseudo-nitzschia delicatissima (Cleve) Heiden complex, Thalassiosira spp., Chaetoceros debilis (Cleve), and Cerataulina pelagica (Cleve) Hendey, and the dinoflagellate Cochlodinium polykrikoides (Margalef). Two of the eight most abundant were HABs, the diatom complex P. delicatissima and the dinoflagellate C. polykrikoides. Sixty-seven species made up the remaining seven percent of the assemblage demonstrating high community diversity despite biomass domination by a handful of species.

The daily cell count mean for the sampling period was $5.385 \mathrm{E}+5$ cells/L $( \pm 5.507 \mathrm{E}+4)$. For purposes of discussion, a bloom was identified when a single species or genus dominated with more than $50 \%$ of total cell abundance. Major phytoplankton blooms were identified as peaks above the mean while minor blooms were peaks below the mean. Occurrences of two or more consecutive peaks where the same species dominated constituted one bloom. A total of seven major blooms consisting of six species or genera were identified for the sample period, with two being HABs. Three minor single-species blooms were also identified (Figure 2).

The first major bloom of the sampling period was a C.polykrikoides bloom which occurred in mid-October 2008 resulting in a reddish-brown discoloration of the surface water and peaking at $9.05 \mathrm{E}+5$ cells/L. The winter months produced scarce biomass overall with three minor blooms occurring from mid-January to early March, dominated by Chaetoceros spp., 
Prorocentrum triestinum (J. Schiller), and Laudaria annulata (Cleve), respectively. The onset of spring brought a series of major blooms, beginning mid-March with two Chaetoceros spp. blooms followed by a C. pelagica bloom in late April. A bloom of Chaetoceros spp. returned almost the entire month of May followed by an S. costatum bloom for the entire month of June. A massive $L$. danicus bloom peaking at $8.137 \mathrm{E}+6$ cells/L (138 std. dev. above the mean) occurred in mid-July. The beginning of August saw a minor bloom without a dominating species (majority Thalassiosira spp.) preceding a double-peaked P. delicatissima complex bloom from mid-August to early-September peaking at $5.22 \mathrm{E}+5$ cells/L. A minor bloom without a dominating species (majority the silicoflagellate Dictyocha spp.) occurred at the end of September 2009.

Six of the seven major blooms consisted of chain-forming diatom species, with the other being the dinoflagellate C.polykrikoides. Two of the seven major blooms were HABs, one being C.polykrikoides, and the second being the diatom P. delicatissima complex which produced a DA spike corresponding with the elevated biomass, peaking at $2.55 \mathrm{ng} / \mathrm{mL}$ on August 31, 2009 (Figure 1d). In situ chl $a$ followed the peaks in cell abundances, but not in the same proportions (Figure 3a). The C. polykrikoides bloom showed the highest chl a per cell relative to the spring blooming diatoms. The summer $P$. delicatissima complex bloom showed the lowest $c h l a$ per cell of the bloom species.

Although diatoms accounted for most of the observed abundance, dinoflagellate populations remained present throughout the year even when diatom numbers decreased (Figure 3b). Percentages of diatoms and dinoflagellates throughout the study period showed that dinoflagellates dominated the community structure during the fall and winter months with a transition to diatom dominated communities in the spring. Dinoflagellates began to show 
increased numbers again in the fall at the end of the sample period, and represented most of the percent HAB species documented, the major exception being the P. delicatissima bloom in August/September, 2009 (Figure 3c).

CCA

Nineteen species occurring in at least $10 \%$ of the weekly samples were used in the CCA (Table I). Forward selection removed variables from analysis which did not contribute significantly in explaining variation in species abundance $(\mathrm{p}>0.05)$ while keeping those variables which were significant (Table II). The CCA produced four canonical axes which explained $46.1 \%$ of the variance in this study (Axis $1=21.6 \%$, Axis $2=12.1 \%$, Axis $3=8.1 \%$, Axis $4=4.3 \%$ ), higher than reported for similar studies (Figueiras et al. 1994; Fermín et al. 1996; Vila \& Maso 2005).

Figure 4a shows the distribution of sample dates in two-dimensional CCA space in relation to the variables included in the model. In general, sample dates follow a clockwise pattern beginning with the fall dates located on the positive side of Axis 1. All fall dates occurred in the top right and bottom right quadrants and were associated with dinoflagellate abundance, nitrate, and percent HAB species. The majority of winter dates fell in the bottom quadrants, and grouped near the center of the biplot. These scores showed a weak relationship to dinoflagellate abundance and several are opposite the temperature vector. Almost all spring dates fell in the lower left quadrant and were associated with diatom abundance and thermal stratification, and lay opposite the temperature, percent HABs, and nitrate vectors. Summer dates were most variable and occurred in all four quadrants, with the majority in the top right and left. These were most related to thermal stratification, DA, and temperature. 
The species scores on the CCA biplot are shown in Figure 4b. The four most divided phytoplankton groups identified by cluster analysis of the CCA biplot scores are color coded in Figure $4 \mathrm{~b}$ and listed in Table 3. The biplot divided the two major phytoplankton taxonomic groups roughly down the center (Axis 1), with diatoms scored on the left associated with thermal stratification, and dinoflagellates on the right associated most closely to the nutrient vectors. Percent HAB species was most closely related to higher nitrate and temperature. The DA vector was aligned with the presence of Pseudo-nitzschia spp.

Group 1 was characterized by the taxa C. debilis, Navicula spp., Ceratium furca (Ehrenberg) Claparéde \& Lachmann , Scrippsiella trochoidea (Stein) Balech ex Loeblich III, Dichtyocha spp., Gonyaulax spp., and Protoperidinium spp. With the exception of the spiral chain-forming diatom $C$. debilis, this group consisted of mixed single-celled taxa, including two potential red-tide forming dinoflagellates C. furca and Protoperidinium spp. This group clustered around the center of the CCA biplot, with no general trend other than the general separation of diatoms and dinoflagellates relative to the variables (Figure 4b).

Group 2 was composed of the taxa Alexandrium spp., Dinophysis acuminata Claparède \& Lachmann, Prorocentrum micans Ehrenberg, Prorocentrum gracile Schütt, and C. polykrikoides, all of which are toxin-producing or red tide forming dinoflagellates (Horner et al. 1997; Curtiss et al. 2008; Holmes \& Lam 1985) (Figure 4b). The perpendicular projections of members of this group indicated a positive relationship with nitrate and a negative relationship to thermal stratification. They fell very close to the logDino vector, which was perpendicular to the temperature vector, indicating that water temperature was a neutral variable for this group. The scores for this group corresponded roughly where fall and winter sample dates clustered in the 
same biplot space (Figure 4a). These results suggest this group preferred well mixed, nutrientrich conditions of fall and winter.

Group 3 consisted of the non-HAB taxa Cylindrotheca closterium (Ehrenberg) Reimann \& J.C.Lewin, Thalassiosira spp., L. danicus, and the DA producing Pseudo-nitzschia seriata (Cleve) H. Peragallo and P. delicatissima complexes (Figure 4b). All of these taxa are diatoms, and with the exception of Thalassiosira spp., are characterized by having long and narrow shaped frustules. Cylindrotheca closterium is the only single-celled member of this group, the remaining being chain-forming species. Except for $L$. danicus, this group fell in the top two biplot quadrants, showing positive relationships to DA, water temperature, and thermal stratification. The DA and nitrate vectors were nearly perpendicular indicating that nitrate concentration was neutral in terms of explaining Pseudo-nitzschia spp. abundance. This region corresponded with the majority of summer sample dates in the same biplot space (Figure $4 a$ ). $L$. danicus, the species with the highest total cell count of the study, fell in the lower left quadrant, a position showing negative relationship to temperature and nitrate, and a slight positive relationship to thermal stratification.

Group 4 consisted of the non-HAB spring chain-forming diatom taxa Chaetoceros spp. and S. costatum (Figure 4b). These species had the second and third highest total cell counts of the study. Their position in the lower left biplot indicated negative relationships with temperature and nitrate, and positive relationship with thermal stratification. All spring sample dates fell in the same biplot quadrant as Group 4 (Figure 4a).

Variance partitioning between the physical and chemical variables indicated that $23.1 \%$ of the variance was explained purely by physical variation in the surface water, while $14.9 \%$ of the variance was explained purely by chemical variation in the surface water (Table 4). This 
shows that although both groups of variables played a role in species composition, the physical characteristics of San Luis Bay had a greater influence than the chemical variables studied.

\section{Co-occurring Species}

Co-occurring species of HABs species were examined both at the bloom peaks and across the whole sample period. At the bloom peaks, co-occurring species were defined when cell abundance was greater than or equal to $13,040 \mathrm{cell} / \mathrm{L}$. Co-occurring species of $C$. polykrikoides on the sample date nearest its bloom peak on October 20, 2008 were $P$. micans, $P$. gracile, and A. sanguinea (K.Hirasaka) G.Hansen \& Ø.Moestrup in order of abundance (data not shown). The $P$. delicatissima complex bloom had two peaks approximately 10 days apart, and each peak exhibited different composition. Co-occurring species on the sample date nearest its first peak on Aug 17, 2009 were C. debilis, Thalassiosira spp., Navicula spp., C. closterium, Bacteriastrum spp., P. seriata complex, and Thalassionema nitzschioides (Grunow) Mereschkowsky in order of abundance. On the sample date nearest its second peak on Aug 27, co-occurring species were C. closterium, the dinoflagellate S. trochoidea, and L. danicus in order of abundance (data not shown).

For the Sorensen similarity analysis across the whole sampling period, nine of the 20 commonly occurring species in the semi-weekly surface data demonstrated at least a 50\% overlap in temporal distribution with at least one other species regardless of abundance (Table V). Diatoms only co-occurred with other diatoms, and dinoflagellates only co-occurred with other dinoflagellates. The four diatoms were all members of Group 2 while the five dinoflagellates were members of Group 3, demonstrating the effectiveness of the CCA in grouping species. However, the degree of pairwise co-occurrence is not clear from the CCA, and not all within-group species co-occurred together often. Members of the P. delicatissima 
complex did not share distribution with members of the $P$. seriata complex in at least $50 \%$ of samples despite being grouped together in the CCA analysis and appearing together in the first $P$. delicatissima complex peak. P. delicatissima complex co-occurred mostly with the non-HAB diatoms C. closterium and Thalassiosira spp. in order of Sorensen similarity, while P. seriata complex did not share at least 50\% distribution with any species. All five dinoflagellates demonstrating at least 50\% overlap with at least one other species were HAB species, and all were grouped together in the CCA. C. polykrikoides co-occurred mostly with D. acuminata, $P$. gracile, and P. micans in order of Sorensen similarity. This analysis may help distinguish cooccurrence across all abundance levels from incidental co-occurrence during an isolated bloom event, and from successional events. In the case of the latter, for example, both Chaetoceros spp. and S. costatum bloomed in June \& July and grouped together in the CCA, most likely due to similar environmental responses, but did not share $>50 \%$ distribution among all samples, thus suggesting a natural succession with little overlap in temporal distribution.

\section{Discussion}

The clustering of taxa based on their CCA scores divided species and genera into groups with shared distributions and environmental variable responses. The HAB dinoflagellates of Group 2 accounted for a majority of the total dinoflagellate abundance (See Figure 3c). The CCA reveals some correlations with this group, most notably its position opposite the thermal stratification vector and adjacent to the nitrate vector. This would suggest that these dinoflagellates appeared near the surface when the water column was well mixed, with elevated nitrate concentrations from upwelled waters as is common in this region. The position of Group 
2 relative to the logDiatom vector suggests that diatom competition is a strong deterrent for HAB dinoflagellates.

Group 2 contained exclusively dinoflagellate HABs including the toxin-producing Alexandrium spp. and Dinophysis spp., as well as the red-tide forming P. micans, P. gracile, and C. polykrikoides, the latter of which experienced a major fall bloom at the beginning of the sampling period. Sorensen similarities $>50 \%$ demonstrated the tightness of this grouping across the sample period. Cochlodinium spp. have historically been found at low background numbers in California but large bloom events have been consistently observed beginning in 2004 ranging from San Mateo to San Diego counties (Curtiss et al. 2008). The largest of these occurred in Santa Cruz and San Luis Obispo counties in the late summer to fall seasons of 2004 and were reported to have affected local oyster farms resulting in high mortalities of seed stock (Curtiss et al. 2008). Cochlodinium spp. are strong swimmers, with flexible nutrient requirements, and can propagate by either pelagic seeding of vegetative cells, typically by offshore movement of lownutrient waters, or by germination of benthic cysts laid down during a previous bloom (Kudela et al. 2008). This has made them well adapted for exploiting new niches due to changing environmental conditions. Temperature and salinity ranges reported for California populations were consistent with those observed for the bloom in this study (Kudela et al. 2008). Upwelling indices and along-shore transport data from the Pacific Fisheries Environmental Laboratory (PFEL) for the San Luis Bay region (36N 122W) indicate that during and prior to the $C$. polykrikoides bloom, there was moderate upwelling and along-shore transport to the south (http://www.pfeg.noaa.gov/). The C. polykrikoides bloom observed in this study during well mixed, nitrate replete conditions may therefore represent a benthic seed germination event 
whereby cysts left from a previous bloom in San Luis Bay had optimal conditions to exploit fall upwelling at the beginning of the sample period.

Akashiwo sanguinea was found with C. polykrikoides at its peak, a pairing that has been observed in other studies (Kudela et al. 2008; Curtiss et al. 2008), and both species were present only for a short time at the beginning of the sample period before disappearing. A foamproducing red tide dominated by $A$. sanguinea was associated with a mass stranding of marine birds in Monterey Bay in 2007 and was preceded by communities dominated by C. polykrikoides (Jessup et al. 2009). A. sanguinea was found to occur in weakly stratified, non-advected water of Monterey Bay in 2005, exhibiting strong swimming behavior with nocturnal vertical migrations to reach nutrients near the pycnocline (Rines et al. 2010). Co-occurring species like these may have similar succession strategies, cyst germination requirements, and life cycles, making them adapted to similar environmental conditions (Anderson \& Rengefors 2006).

Group 3 contained the two DA producing Pseudo-nitzschia groups, with a major summer bloom produced in August 2009 by P. delicatissima complex, as well as several other non-HAB diatoms. The correlation of this group with higher surface temperatures and thermal stratification was congruent with the summer sampling dates which clustered in the same area. The low positive to negative correlation with surface nitrate suggests this group is low nutrient tolerant, however, the lag time between a spike in nitrate and an increase in growth resulting in the subsequent decline of nitrate could confound this interpretation. Similarly, the chain-forming spring diatoms of Group 4 scored opposite the nitrate vector, not because they do not require these nutrients, but more likely because their large numbers resulted in a decline in these nutrients which manifested as negative correlation in the CCA. Pseudo-nitzschia delicatissima complex correlated the strongest with the DA vector, as expected due to the DA peak on August 
31, 2009 which occurred shortly after the second P. delicatissima complex peak on August 27, 2009 (Figure 1d).

The relaxation of the water column could allow well mixed and nutrient saturated diatoms to experience a population increase near the well-lit surface before sinking out of the water column. The spring blooming diatoms (Chaetoceros, Skeletonema) exhibit double and triple peaked surface blooms correlated with thermal stratification and cold water in the CCA. The P. delicatissima complex bloom from mid-August to early September was also correlated with thermal stratification in the CCA, but unlike the spring diatoms, with warm water temperature associated with summer. This was a double peaked bloom which coincided with the two peaks in the thermal stratification data during August (Figure 1c). Upwelling indices from PFEL indicate that moderate upwellings were continuing into summer after the large spring upwellings, and although it showed fluctuations between upwelling and relaxation, the indices did not indicate onshore movement to suggest advection. Additionally, PFEL along-shore transport data during August 2009 showed very little water movement in the north or south directions. Since upwellings can introduce diatom resting spores into the water column to influence succession (Garrison 1979), a succession of summer species from Group 3 (L. danicus, Thalassiosira spp., P. delicatissima complex) could have been fueled by pulses of small summer upwellings followed by stratification. This could be a possible mechanism for the sequence of summer events seen in this study, and provides an alternate driver for Pseudo-nitzschia spp. blooms.

Pseudo-nitzschia blooms in California tend to be propogated via advection of offshore or alongshore waters and can flourish with the right balance of upwelling and stratification (Trainer et al. 2000). Strong southward winds between Morro Bay and Point Concepcion drive coastal 
upwellings and at the same time transport Pseudo-nitzschia populations southward (Trainer et al. 2000). Similarly, a DA producing P. pseudodelicatissima population off the coast of Washington state developed in an offshore eddy and was transported to the coast where upwellings fueled a bloom (Trainer et al. 2002). Pseudo-nitzschia blooms are not limited to this mechanism, as they have also been observed during spring upwellings (Trainer et al. 2000) and different species may have difference responses to environmental conditions (Klein et al. 2010). These diatoms appear to be tolerant to large changes in water column stability or may benefit from these fluctuations. It appears that blooms in San Luis Bay may occur either when resting spores are introduced by upwellings, or when populations from the north are transported south to mingle with coastal upwellings.

Cylindrotheca closterium shared $>50 \%$ distribution with $P$. delicatissima complex, and was found in both $P$. delicatissima peaks. Cylindrotheca closterium has been observed to occur with $P$. delicatissima among other community members during summertime mucilage aggregate formation in the Adriatic Sea (Totti et al. 2005 and references therein). These events coincided with a period of high atmospheric pressure having an influence on water mass movement (Totti et al. 2005). C. closterium co-occurred with $P$. pungens ( $P$. seriata complex) during a similar event in the Sea of Marmara which was correlated with low N:P ratios (Tufekci et al. 2010). The presence of C. closterium could serve as an indicator or predictor of Pseudo-nitzschia spp. events or conditions favorable for a Pseudo-nitzschia spp. event in San Luis Bay.

The variables measured in this study explained $46.1 \%$ of the variance in phytoplankton composition according to multivariate analysis by CCA. Partitioning of variance analysis indicated that physical variables explained more of the variability than chemical variables, emphasizing the importance of temperature and water column stability. Several of the bloom- 
forming HAB species in San Luis Bay, the dinoflagellate C. polykrikoides and diatom $P$. delicatissima complex exhibited environmental responses which seem contradictory to the classic diatom/dinoflagellate succession paradigm where diatoms bloom during cold nutrient rich upwellings, dinoflagellates bloom during periods of warm stratification, and red tide species bloom when a transition between these conditions occurs (Margalef 1978).

Cochlodinium polykrikoides bloomed during a high nutrient, well mixed, fall upwelling and co-occurred most with $P$. micans and $P$. gracile, appearing to behave like a classic diatom. Many dinoflagellates, especially chain-forming species such as C. polykrikoides, are capable of swimming fast enough to vertically migrate and thrive during turbulent conditions, and stratification may be a secondary condition of blooms (Smayda 2002). This may have allowed C. polykrikoides to germinate and multiply in turbulent water in the absence of competition by spring diatoms.

Pseudo-nitzschia delicatissima complex bloomed during summer stratification episodes following small upwelling events, and co-occurred most with C. closterium. This is similar to the mechanism described by Trainer et al. (2000) but without the seeding of cells by advection of water into the region. The stratification of the water column could be a secondary bloom condition after the primary condition of turbulent waters stimulated growth, as described by Smayda (2002). This mechanism appears to have driven a P. delicatissima complex germination and bloom event in this study without advection of water into San Luis Bay. This study has shown that several HAB species with flexible life strategies have bloomed in San Luis Bay without advection, and that water column instabilities within seasons have played an important role in an unconventional way. The identification and life history examination of species which 
tend to co-occur with HABs both during bloom peaks and non-blooming periods may help further elucidate conditions which are favorable for HAB events.

\section{References}

Anderson, D.M. \& Rengefors, K. 2006. Community assembly and seasonal succession of marine dinoflagellates in a temperate estuary: the importance of life cycle events. Limnol. Oceanogr. 51(2):860-873.

Briand, F. J.-P. 1976. Seasonal variations and associations of Southern California nearshore phytoplankton. J. Ecology. 64:821-835.

Curtiss, C.C., Langlois, G.W., Busse, L.B., Mazillo, F., and Silver, M.W. 2008. The emergence of Cochlodinium along the California Coast (USA). Harmful Algae. 7:337-346.

Delmas, D., Herbland, A., \& Maestrini, S.Y. 1992. Environmental conditions which lead to increase in cell density of the toxic dinoflagellates Dinophysis spp. in nutrient-rich and nutrientpoor waters of the French Atlantic coast. Mar. Ecol. Prog. Series. 89:53-61.

Fager, E.W. 1957. Determination and analysis of recurrent groups. Ecology. 38:586-595.

Fermín, E.G., Figueiras, F.G., Arbones, B., \& Villarino, M.L. 1996. Short-term scale development of a Gymnodinium catenatum population in the Ria De Vigo (NW Spain). J. Phycology. 32:212-221. 
Figueiras, F.G., Jones, K.J., Mosquera, A.M., Alvarez-Salgado, X.A., Edwards, A., and MacDougall, N. 1994. Red tide assemblage formation in an estuarine upwelling ecosystem: Ria de Vigo. J. Plankton Research. 16(7):857-878.

Figueiras, F.G., Pitcher, G.C., \& Estrada, M. 2006. Harmful Algal Bloom Dynamics in Relation to Physical Processes. In Granéli, E. \& Turner, J.T. [Eds.] Ecology of Harmful Algae. Springer, Berlin, Heidelberg, New York, pp. 127-138.

Garrison, D. L. 1979. Monterey Bay phytoplankton. I. Seasonal cycles of phytoplankton assemblages. J. Plankton Research. 1:241-265.

Graham, L. E., Graham, J. M., and Wilcox, L. W. 2009. Algae. $2^{\text {nd }}$ Ed. Benjamin Cummings, San Francisco, CA, 616 pp.

Hasle, G.R. \& Syvertson, E.E. 1997. Marine Diatoms. In Tomas, C. R. [Ed.] Identifying Marine Phytoplankton. Academic Press, San Diego, CA, pp. 5-385.

Holmes, P.R., and Lam, C.W.Y. 1985. Red Tides in Hong Kong Waters-Response to a Growing Problem. Asian Marine Biology. 2:1-10.

Horner, R.A. 2002. A Taxonomic Guide to Some Common Marine Phytoplankton. Biopress Ltd, Bristol, UK, 195 pp.

Horner, R. A., Garrison, D. L., \& Plumley, F. G. 1997. Harmful algal blooms and red tide problems on the U.S. west coast. Limnol. Oceanogr. 42:1076-1088. 
Jessup, D.A., Miller, M.A., Ryan, J.P., Nevins, H.M., Kerkering, H.A., Mekebri, A., Crane, D.B., Johnson, T.A., \& Kudela, R.M. 2009. Mass stranding of marine birds caused by a surfactant-producing red tide. PLoS ONE. 4(2):E4550. doi:10.1371/journal.pone.0004550.

Jester, R., Lefebvre, K., Langlois, G., Vigilant, V., Baugh, K., \& Silver, M. W. 2009. A shift in the dominant toxin-producing algal species in central California alters phycotoxins in food webs. J. Harmful Algae. 8:291-298.

Johnson, K.S., Petty, R.L., \& Thomsen, J. 1985. Flow-injection analysis for seawater micronutrients. In Zirino, A. [Ed.] Mapping Strategies in Chemical Oceanography. American Chemical Society, Washington, DC, pp. 7-30.

Klein, C., Claquin, P., Bouchart, V., Le Roy, B., \& Veron, B. 2010. Dynamics of Pseudonitzschia spp. and domoic acid production in a macrotidal ecosystem of the eastern English Channel. Harmful Algae. 9(2):218-226.

Kudela, R.M., Lane, J.Q., \& Cochlan, W.P. 2008. The potential role of anthropogenically derived nitrogen in the growth of harmful algae in California, USA. Harmful Algae. 8(1):103110.

Kudela, R.M., Ryan, J.P., Blakely, M.D., Lane, J.Q., \& Peterson, T.D. 2008. Linking the physiology and ecology of Cochlodinium to better understand harmful algal bloom events: A comparative approach. Harmful Algae. 7:278-292.

Legendre, P. 2007. Studying beta diversity: ecological variation partitioning by multiple regression and canonical analysis. J. Plant Ecology. doi: 10.1093/jpe/rtm001. 
Leps, J \& Smilauer, P. 2003. Multivariate analysis of ecological data using CANOCO. Cambridge University Press, Cambridge, UK, 269 pp.

Litaker, R. W., Stewart, T. N., Eberhart, B-T. L., Wekell, J. C., Trainer, V. L., Kudela, R. M., Miller, P. E., Roberts, A., Hertz, C., Johnson, T. A., Frankfurter, G., Smith, G. J., Schnetzer, A., Schumacker, J., Batian, J. L., Odell, A., Gentien, P., Le Gal, D., Hardison, D. R., \& Tester, P. A. 2008. Rapid Enzyme Linked Immunosorbent Assay For The Detection of the Algal Toxin Domoic Acid. J. Shellfish Research. 27(5):1301-1310.

Margalef, R. 1978. Life-forms of phytoplankton as survival alternatives in an unstable environment. Oceanologica acta. 1:493-509.

McCune, B. \& Grace, J.B. 2002. Analysis of Ecological Communities. MJM Software Design, Gleneden, OR, 300 pp.

Melton, C., Washburn, L, \& Gotschalk, C. 2009. Wind relaxations and poleward flow events in a coastal upwelling system on the central California coast. J. of Geophysical Research. 114, C11016, doi:10.1029/2009JC005397.

Rines, J.E.B., McFarland, M.N., Donaghay, P.L., \& Sullivan, J.M. 2010. Thin layers and species-specific characterization of the phytoplankton community in Monterey Bay, California, USA. Continental Shelf Research. 30:66-80. 
Schofield, O., Kerfoot, J., Mahoney, K., Moline, M., Oliver, M., Lohrenz, S., and Kirkpatrick, G. 2006. Vertical migration of the toxic dinoflagellate Karenia brevis and the impact on ocean optical properties. J. of Geophysical Research. Vol. II, C06009, doi: 10.1029/2005JC003115, 2006.

Sellner, K. G., Doucette, G. J., Kirkpatrick, G. J. 2003. Harmful algal blooms: causes, impacts, and detection. J. Industrial Microbiology \& Biotechnology. 30:383-406.

Smayda, T. J. 1980. Phytoplankton Species Succession. In Morris, I. [Ed.] The Physiological Ecology of Phytoplankton.University of California Press, Berkeley and Los Angeles, CA, pp. 493-570.

Smayda, T. J. 2002. Turbulence, water mass stratification and harmful algal blooms: an alternative view and frontal zones as "pelagic seed banks”. Harmful Algae. 1:95-112.

Steidinger, K.A. \& Tangen, K. 1997. Dinoflagellates. In Tomas, C. R. [Ed.] Identifying Marine Phytoplankton. Academic Press, San Diego, CA, pp. 387-589.

Totti, C., Cangini, M., Ferrari, C., Kraus, R., Pompei, M., Pugnetti, A., Romagnoli, T., Vanucci, S., \& Socal, G. 2005. Phytoplankton size distribution and community structure in relation to mucilage occurrence in the northern Adriatic Sea. Science of The Total Environment. 353(13):204-217.

Trainer, V.L., Adams, N.G., Bill, B.D., Stehr, C.M., Wekell, J.C., Moeller, P., Busman, M., \& Woodruff, D. 2000. Domoic Acid Production Near California Coastal Upwelling Zones. Limnology and Oceanography. 45(8):1818-1833. 
Trainer, V.L., Hickey, B.M., \& Homer, R.A. 2002. Biological and physical dynamics of domoic acid production off the Washington coast. Limnol. \& Oceanography. 47(5):1438-1446.

Ter Braak, C.J.F. \& Šmilauer, P. 2002. CANOCO Reference Manual and CanoDraw for Windows User's Guide. Biometris, Wageningen University, Netherlands, 500 pp.

Tufekci, V., Balkis, N., Polat Beken, C., Ediger, D., \& Mantikci, M. 2010. Phytoplankton composition and environmental conditions of a mucilage event in the Sea of Marmara. Turk. J. Biol. 34:199-210.

Utermöhl, von H. 1931. Neue Wege in der quantitativen Erfassung des Planktons. (Mit besondere Beriicksichtigung des Ultraplanktons). Verh. Int. Verein. Theor. Angew. Limnol. 5:567-595.

Venrick, E. L. 1971. Recurrent groups of diatom species in the North Pacific. J. Ecology. 52:614-625.

Vila, M., \& Masó, M. 2005. Phytoplankton functional groups and harmful algal species in anthropogenically impacted waters of the NW Mediterranean Sea. Scientia Marina. 69:31-45. 
Table I. Taxa Occurring In At Least $10 \%$ of Weekly Samples (N=51) Sorted by Abundance

\begin{tabular}{|c|c|c|c|c|c|c|c|}
\hline Name & $\begin{array}{c}\text { Mean Cell } \\
\text { Count } \\
(\text { Cells/L) }\end{array}$ & Stand.Dev. & $\begin{array}{c}\text { Total Cell } \\
\text { Count }(\text { Cells/L) }\end{array}$ & Kurtosis & $\begin{array}{c}\% \\
\text { Occurrence }\end{array}$ & Group & HAB \\
\hline Leptocylindrus danicus & 181800 & 1213000 & $9.27 \mathrm{E}+06$ & 51.012 & 13.7 & Diatom & $\mathrm{N}$ \\
\hline Skeletonema costatum & 125300 & 536200 & $6.39 \mathrm{E}+06$ & 25.818 & 13.7 & Diatom & $\mathrm{N}$ \\
\hline Chaetoceros spp. & 123300 & 329400 & $6.29 \mathrm{E}+06$ & 7.606 & 31.4 & Diatom & $\mathrm{N}$ \\
\hline Pseudo-nitzschia delicatissima group & 24410 & 93010 & $1.25 \mathrm{E}+06$ & 18.345 & 19.6 & Diatom & $\mathrm{Y}$ \\
\hline Cochlodinium polykrikoides & 23190 & 127000 & $1.18 \mathrm{E}+06$ & 49.505 & 15.7 & Dinoflagellate & $\mathrm{Y}$ \\
\hline Thalassiosira spp. & 22670 & 84740 & $1.16 \mathrm{E}+06$ & 39.512 & 43.1 & Diatom & $\mathrm{N}$ \\
\hline Chaetoceros debilis & 12660 & 49340 & 645800 & 8.529 & 9.8 & Diatom & $\mathrm{N}$ \\
\hline Cylindrotheca closterium & 4221 & 6261 & 215265 & 4.952 & 37.3 & Diatom & $\mathrm{N}$ \\
\hline Prorocentrum micans & 3458 & 9689 & 176374 & 18.152 & 25.5 & Dinoflagellate & $\mathrm{Y}$ \\
\hline Pseudo-nizschia seriata group & 3377 & 8164 & 172203 & 11.888 & 13.7 & Diatom & $\mathrm{Y}$ \\
\hline Prorocentrum gracile & 2573 & 4277 & 131235 & 9.339 & 27.5 & Dinoflagellate & $\mathrm{Y}$ \\
\hline Dichtyocha spp. & 2546 & 11949 & 129842 & 50.943 & 11.8 & Silicoflagellate & $\mathrm{N}$ \\
\hline Alexandrium spp. & 1756 & 2435 & 89569 & 8.326 & 27.5 & Dinoflagellate & $\mathrm{Y}$ \\
\hline Navicula spp. & 1552 & 4198 & 79150 & 48.38 & 17.6 & Diatom & $\mathrm{N}$ \\
\hline Gonyaulax spp. & 1184 & 1511 & 60398 & 11.878 & 11.8 & Dinoflagellate & $\mathrm{N}$ \\
\hline Scrippsiella trochoides & 1171 & 1981 & 59704 & 35.847 & 13.7 & Dinoflagellate & $\mathrm{N}$ \\
\hline Dinophysis acuminata & 1157 & 1366 & 59010 & 16.854 & 15.7 & Dinoflagellate & $\mathrm{Y}$ \\
\hline Ceratium furca & 1075 & 1206 & 54843 & 10.099 & 11.8 & Dinoflagellate & $\mathrm{N}$ \\
\hline Protoperidinium spp. & 980 & 870 & 49982 & 15.959 & 13.7 & Dinoflagellate & $\mathrm{N}$ \\
\hline
\end{tabular}


TABLE II. Forward selection of variables sorted by $\lambda_{A}$, the marginal significance of each variable by itself. Variables with pvalues $>0.05$ were deselected from analysis (shaded).

\begin{tabular}{|l|lcr|}
\hline Variable & \multicolumn{3}{|c|}{ P } \\
\hline \% HABs & 0.005 & 0.002 & 3.48 \\
logDiat & 0.005 & 0.002 & 7.03 \\
logDino & 0.004 & 0.002 & 5.26 \\
Temp & 0.003 & 0.002 & 4.75 \\
Strat & 0.003 & 0.002 & 3.96 \\
NO3 & 0.002 & 0.006 & 3.56 \\
DA & 0.002 & 0.022 & 3.26 \\
Chl $a$ & 0.002 & 0.066 & 2.54 \\
Shannon & 0.001 & 0.182 & 1.41 \\
NH4 & 0.001 & 0.404 & 1.05 \\
Salinity & 0.001 & 0.506 & 0.86 \\
\hline
\end{tabular}

TABLE III. Clustering on species scores for the four canonical axes. HABs taxa are shaded.

\begin{tabular}{|llll|}
\hline Group 1 (Blue) & Group 2 (Red) & Group 3 (Green) & Group 4 (Yellow) \\
\hline C. debilis & Alexandrium spp. & C. closterium & Chaetoceros spp. \\
Navicula spp. & D. acuminata & Thalassiosira spp. & S. costatum \\
C. furca & P. gracile & L. danicus & \\
S. trochoides & P. micans & P. delicatissima group & \\
Dichtyocha spp. & C. polykrikoides & P. seriata group & \\
$\begin{array}{l}\text { Gonyaulax spp. } \\
\text { Protoperidinium }\end{array}$ & & & \\
spp. & & & \\
\hline
\end{tabular}


TABle IV. Variance Partitioning of Physical and Chemical Variables

\begin{tabular}{|lcc|}
\hline Source & Variance & Percentage \\
\hline Pure Physical & 0.006 & 23.1 \\
Shared & 0.000 & 0.0 \\
Pure Chemical & 0.003 & 14.9 \\
Residual & 0.020 & 62.0 \\
\hline
\end{tabular}

TABLE V. Co-occurring species with at least $50 \%$ Sorensen similarity (presence/absence) based on semiweekly sampling. HABs are shaded.

\begin{tabular}{|c|c|c|c|c|c|}
\hline Diatoms & C. closterium & L. danicus & P. delicatissima & Thalassiosira spp. & \\
\hline C. closterium & \multirow{4}{*}{$\begin{array}{c}- \\
57.1 \\
63.6 \\
73.0\end{array}$} & \multirow{4}{*}{$\begin{array}{c}57.1 \\
-\end{array}$} & \multirow[t]{2}{*}{63.6} & \multirow[t]{2}{*}{73.0} & \\
\hline L. danicus & & & & & \\
\hline P. delicatissima & & & \multirow{2}{*}{$\begin{array}{c}- \\
56.6\end{array}$} & \multirow{2}{*}{$\begin{array}{c}56.6 \\
-\end{array}$} & \\
\hline Thalassiosira spp. & & & & & \\
\hline Dinoflagellates & Alexandrium spp. & C. polykrikoides & D. acuminata & P. gracile & P. micans \\
\hline Alexandrium spp. & \multirow{5}{*}{52.4} & & & 52.4 & \multirow{3}{*}{54.5} \\
\hline C. polykrikoides & & - & 69.2 & 56.4 & \\
\hline D. acuminata & & 69.2 & - & 54.1 & \\
\hline P. gracile & & 56.4 & 54.1 & - & 63.6 \\
\hline P. micans & & 54.5 & & 63.6 & - \\
\hline
\end{tabular}


Figure 1a

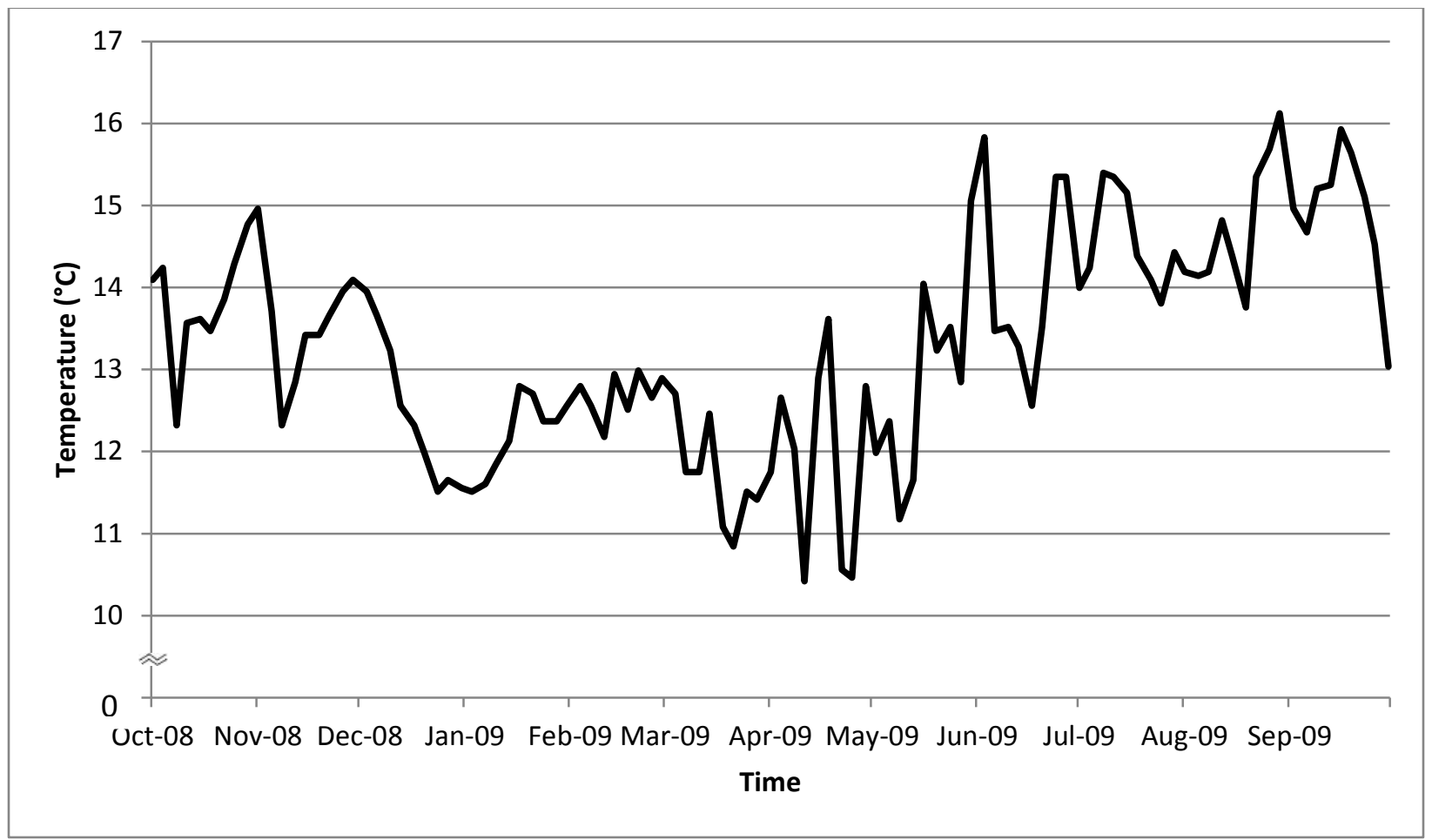

Figure 1b

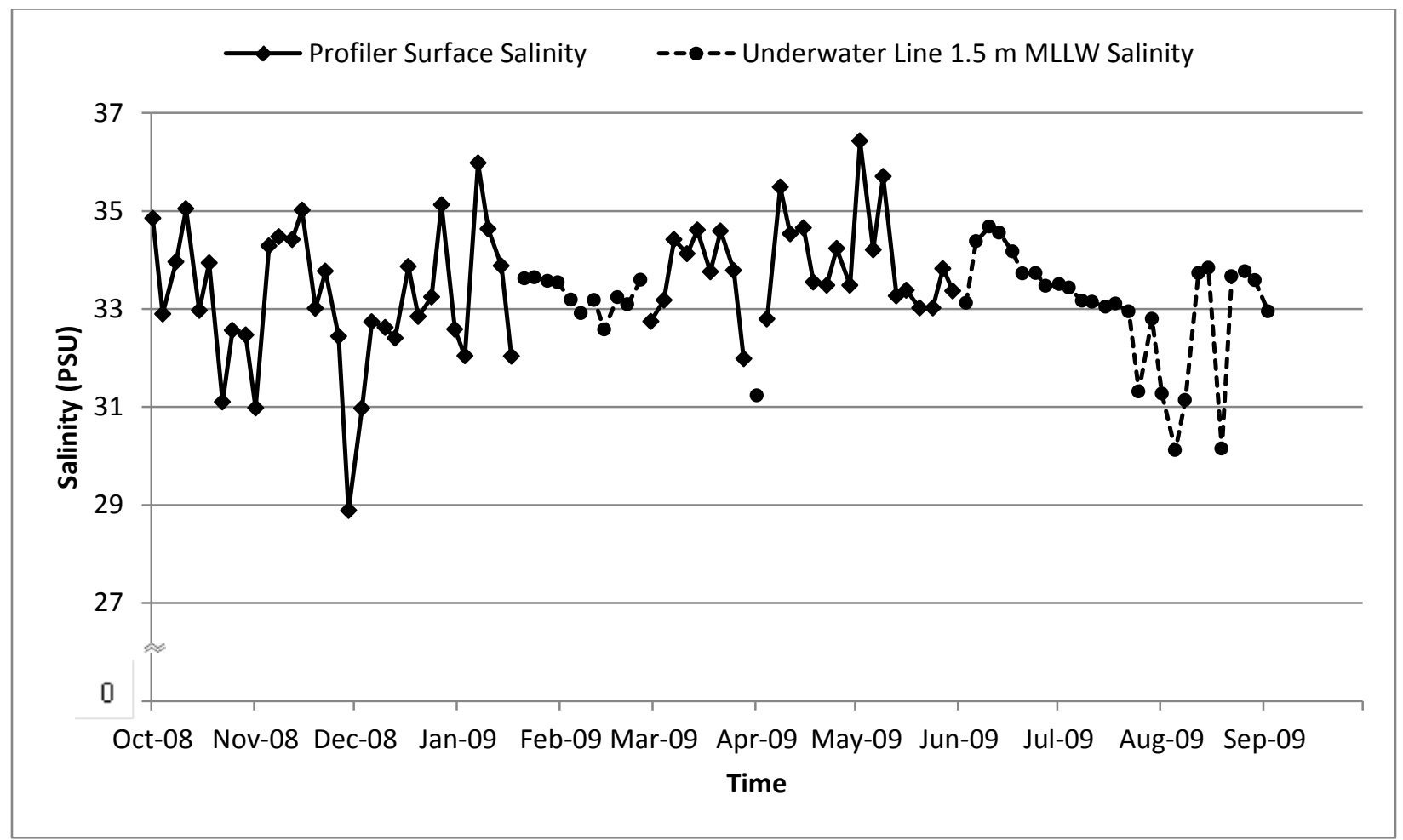


Figure 1c

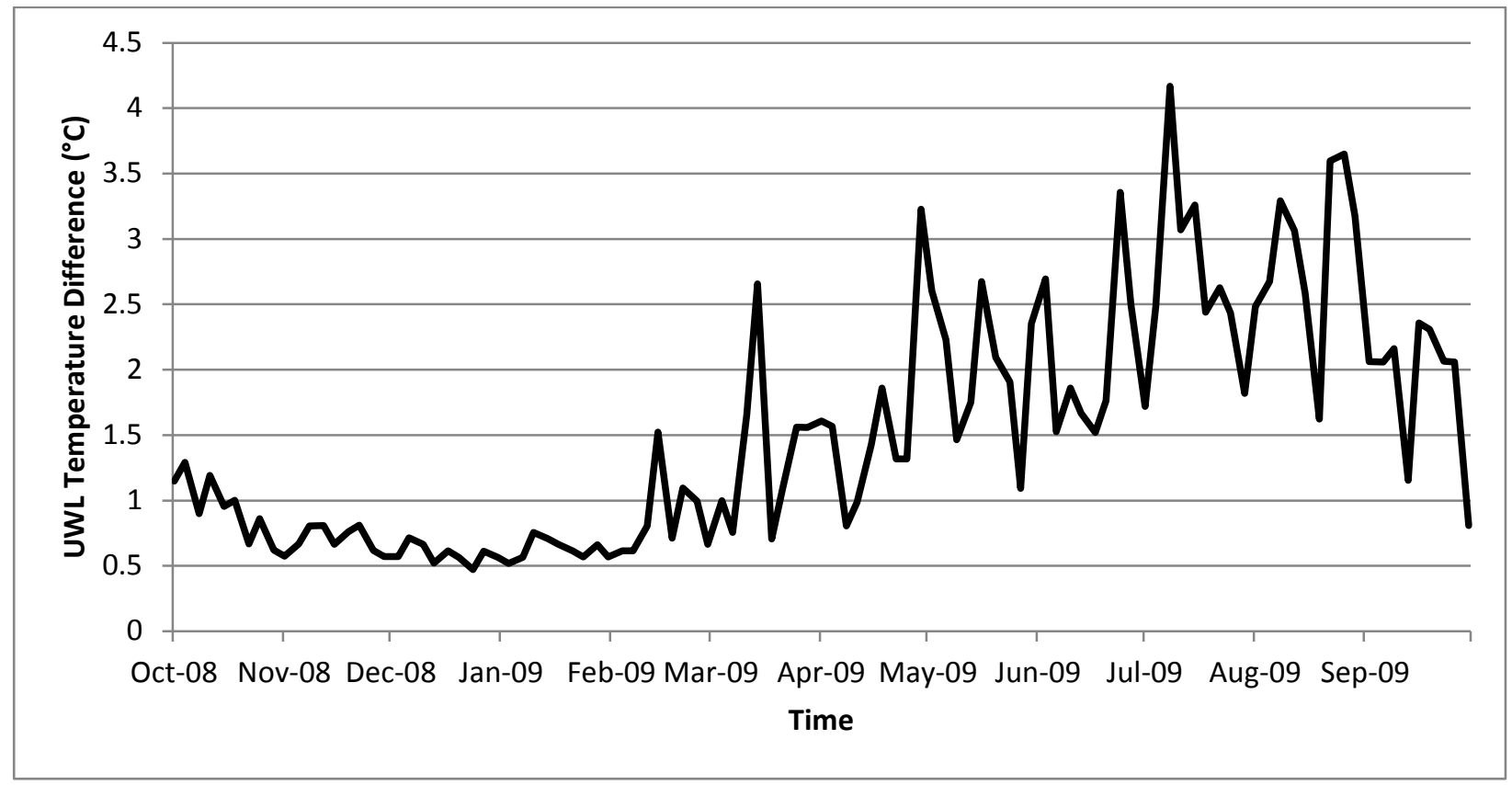

Figure 1d

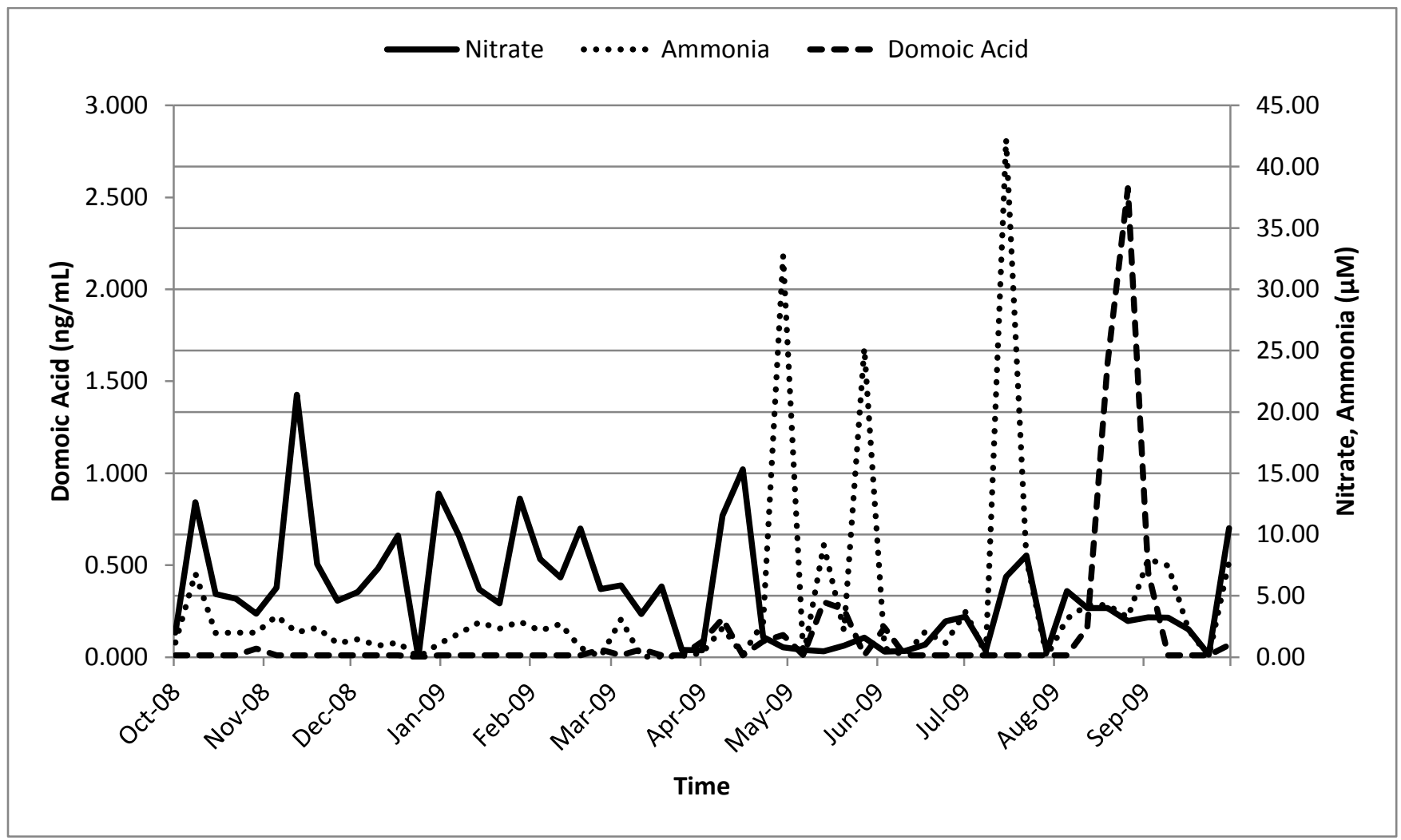


Figure 2

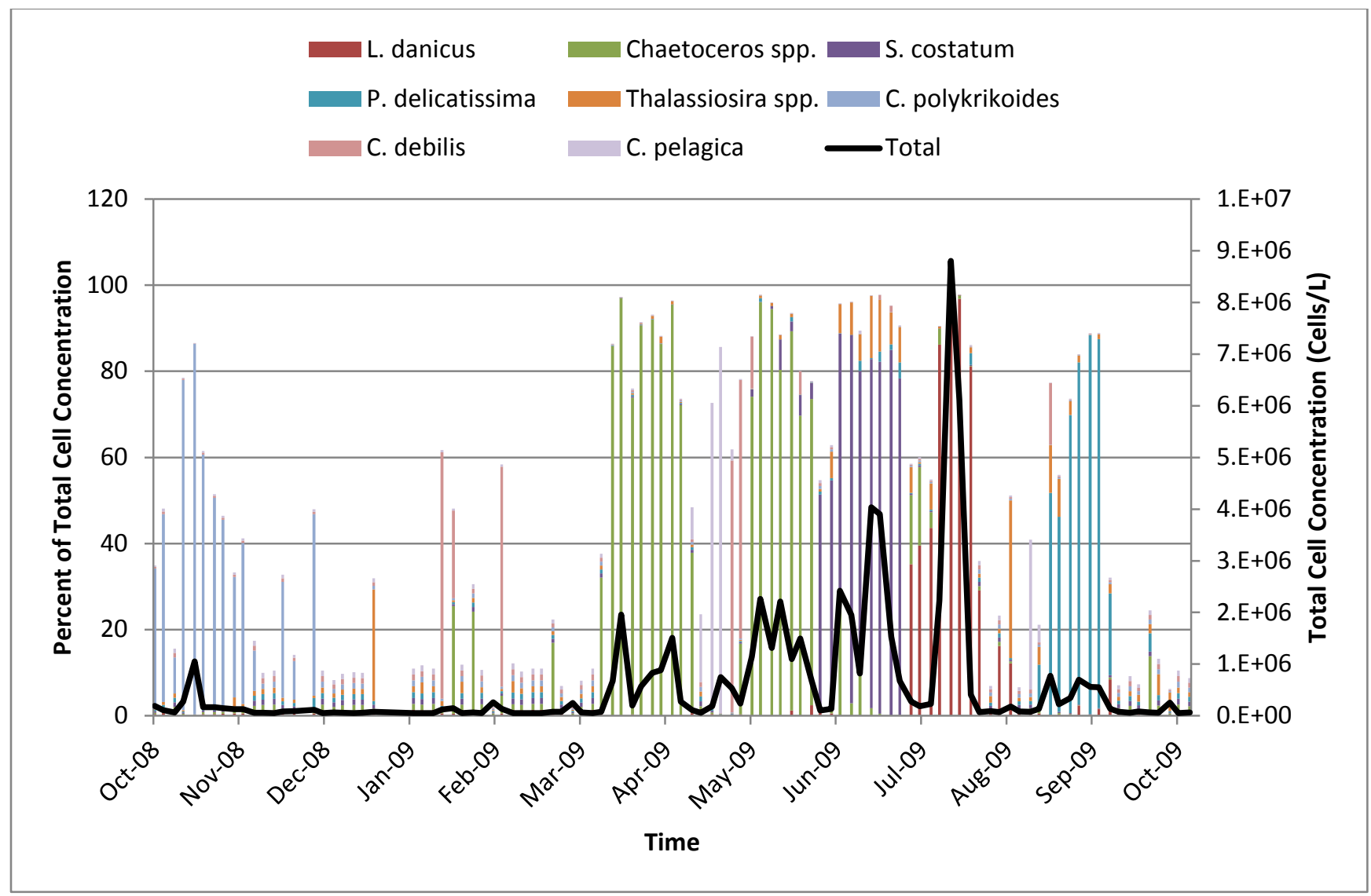


Figure 3a

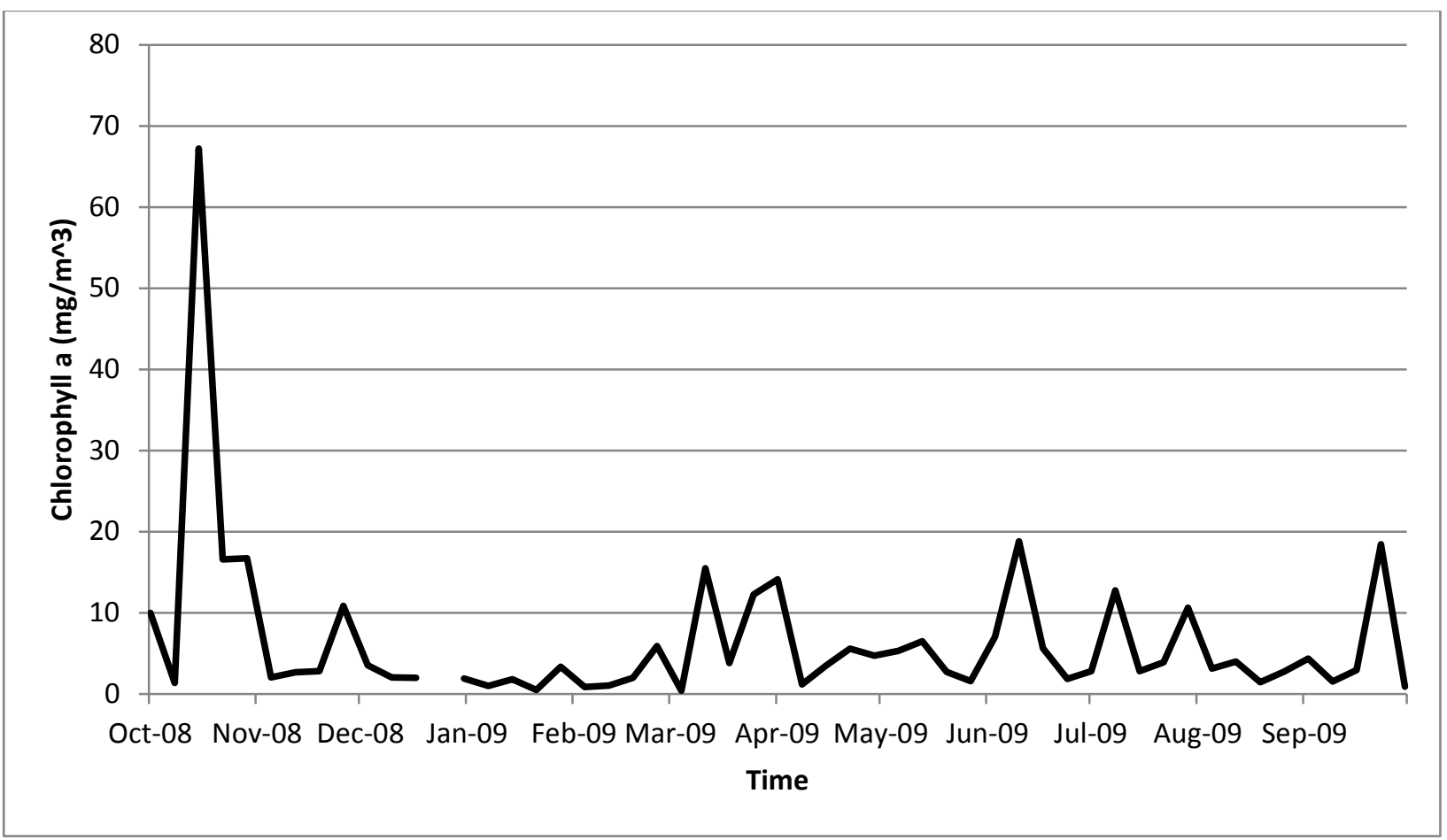

Figure 3b

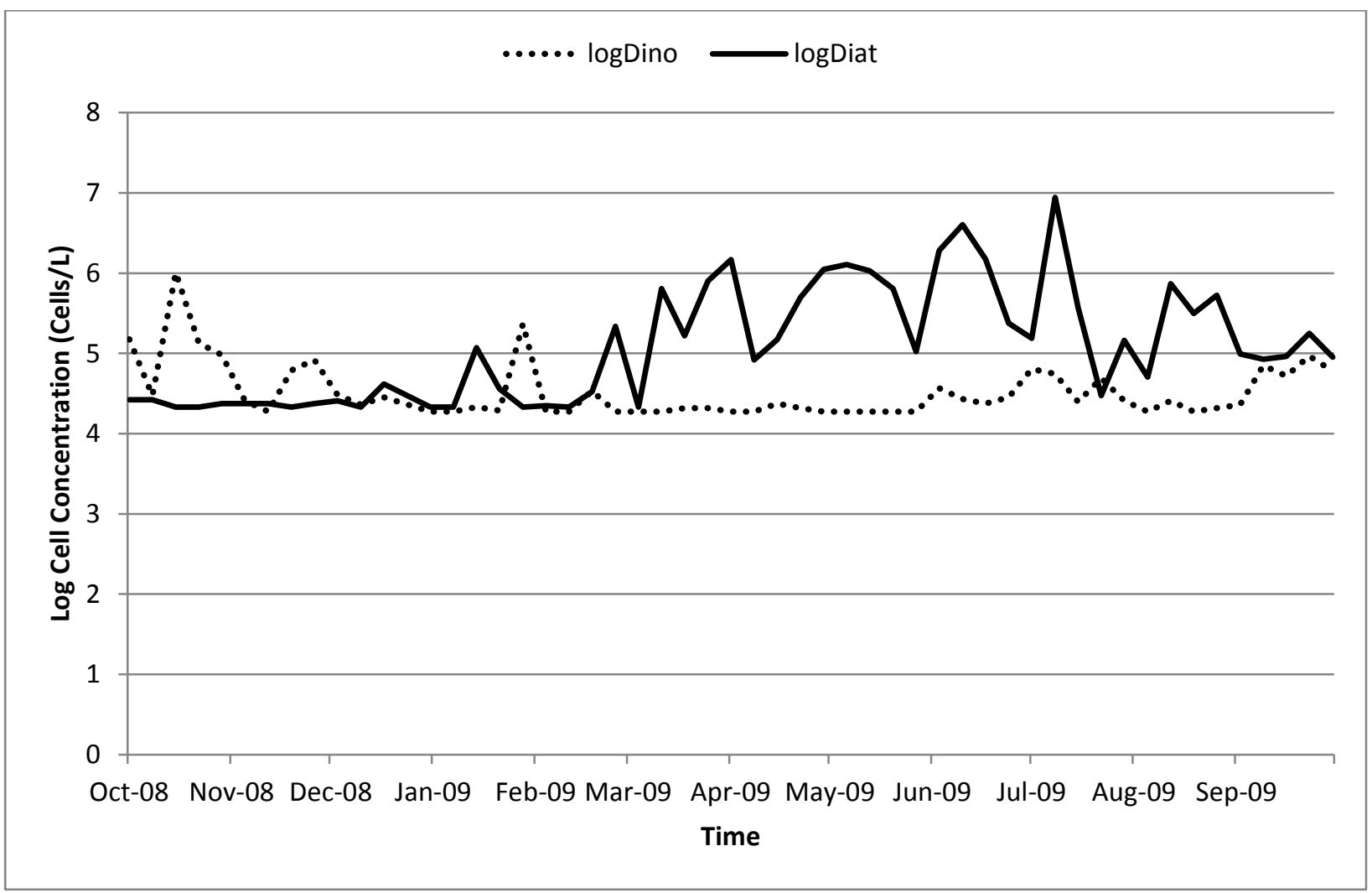


Figure 3c

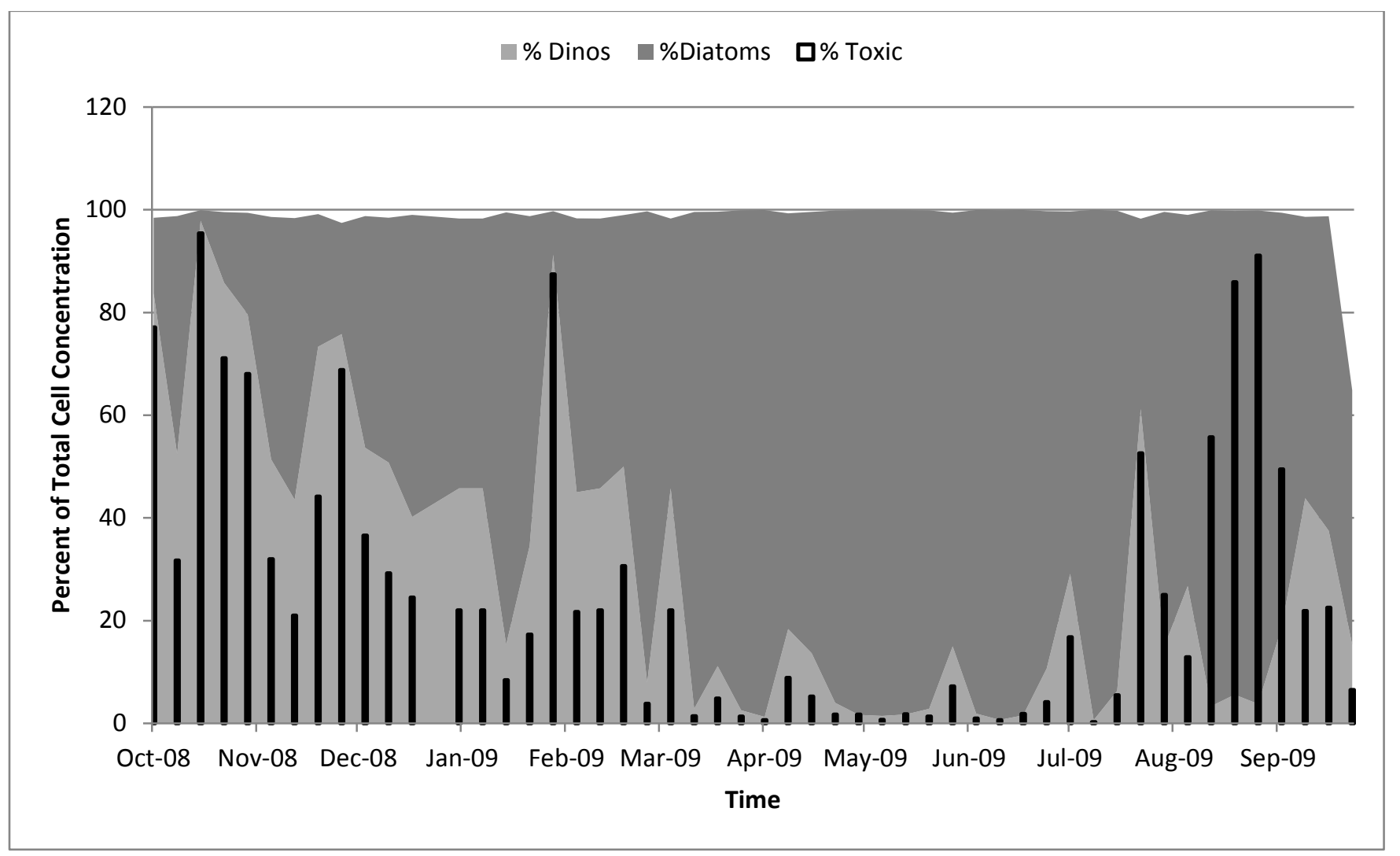


Figure 4a

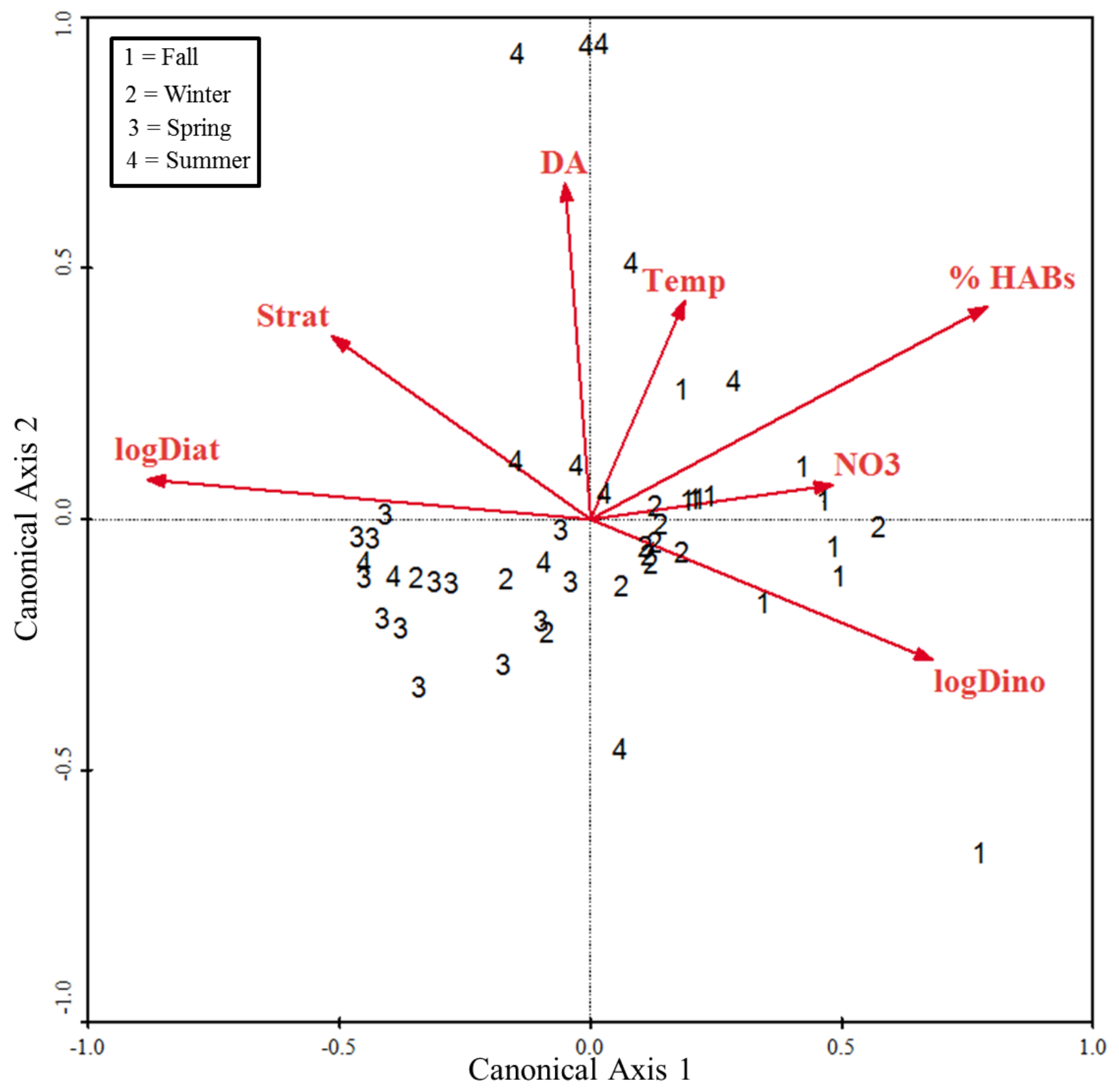


Figure 4b

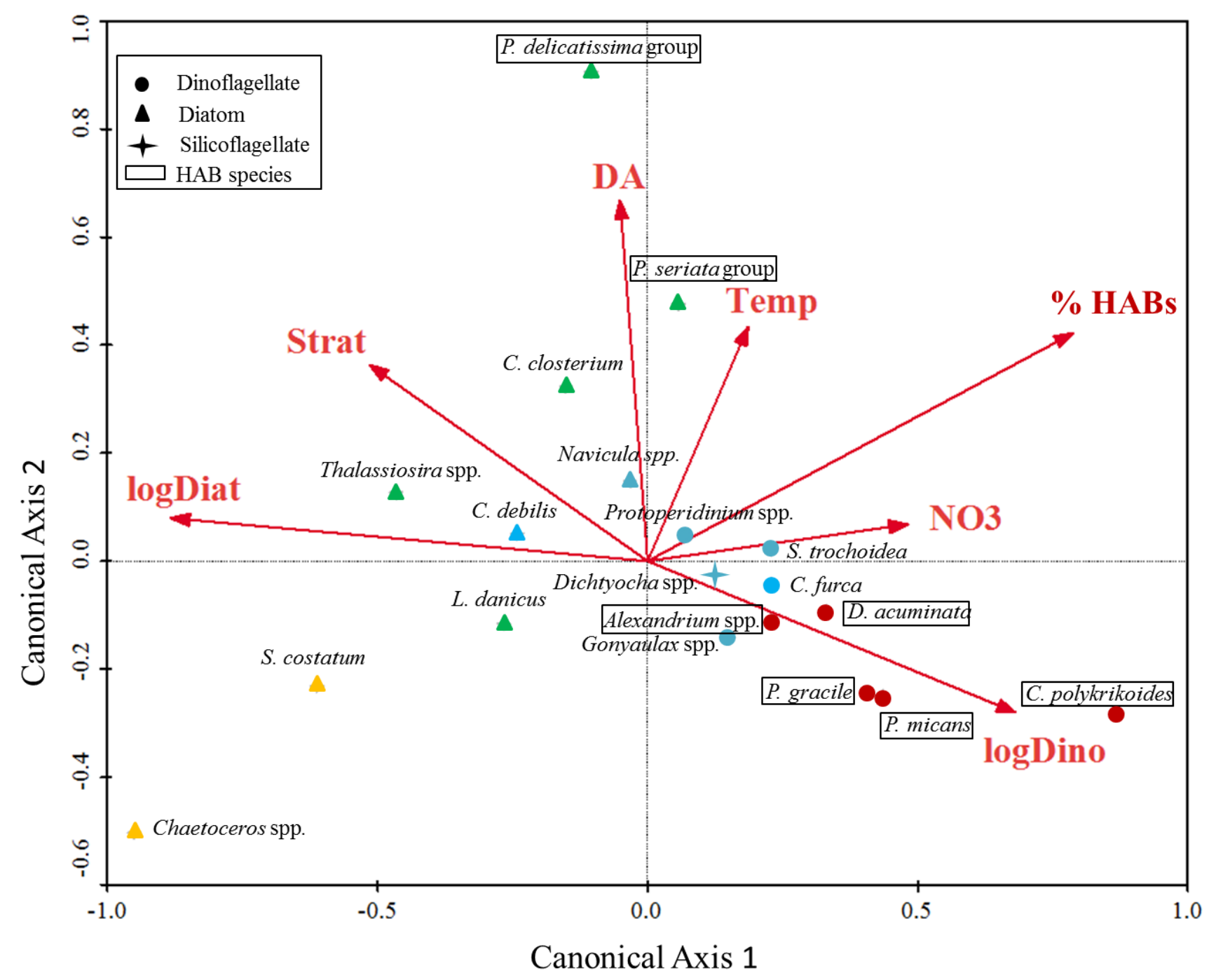


Figure Captions

FIG. 1. Time series of some of the variables used in the canonical correspondence analysis (CCA). Sampling period is Oct 6, 2008 to Oct 5, 2009 unless otherwise noted. (a) Twiceweekly temperature time series taken from the Cal Poly Pier's underwater line (UWL) at $1.5 \mathrm{~m}$ mean low low water level (MLLW). (b) Twice-weekly salinity time series created with surface measurements from the Cal Poly Pier's vertical profiler, and measurements from Cal Poly Pier’s UWL at 1.5 m MLLW. Time series ends Sept 7, 2009. (c) Twice-weekly time series of difference between temperature measurements taken at 1.5m MLLW and 7.5 m MLLW from Cal Poly Pier’s UWL. (d) Weekly silicate, nitrate, and ammonia time series from surface water samples.

FIG. 2. Twice-weekly total cell concentration (solid line) plotted over stacked histogram of the percent of total of the top eight most abundant taxa.

FIG. 3. (a) Weekly chlorophyll atime series taken from surface water samples. (b) Weekly log diatom and log dinoflagellate time series calculated from surface water cell concentrations. (c) Area plot of weekly percent diatoms and percent dinoflagellates with percent HAB taxa histogram superimposed.

FIG. 4. Canonical correspondence analysis (CCA) biplots in two-dimensional CCA space defined by Axes 1 and 2.Variables are displayed as vectors, the lengths and directions of which are dependent on their scores in the first two axes. The strength of variables associated with sample dates or species can be seen by the perpendicular projection of the biplot score onto the arrow or extension of the arrow in either the positive or negative direction. (a) Weekly sample dates plotted in CCA space and coded by season. (b) Most common species which occurred in at least 
$10 \%$ of weekly samples plotted in CCA space. Color coded groups were determined by cluster analysis of the species CCA biplot scores (Table 2). 
Table S1. Surface species in order of abundance. Shaded represent 93\% of abundance.

\begin{tabular}{|c|c|c|c|c|c|}
\hline Name & $\begin{array}{c}\text { Mean } \\
(\text { Cells/L) }\end{array}$ & Stand.Dev. & $\begin{array}{c}\text { Sum } \\
(\text { Cells/L) }\end{array}$ & $\begin{array}{l}\% \text { of } \\
\text { total }\end{array}$ & Group \\
\hline Leptocylindrus danicus & 160100 & 989200 & $1.62 \mathrm{E}+07$ & 29.7 & Diatom \\
\hline Chaetoceros spp. & 149700 & 395600 & $1.51 \mathrm{E}+07$ & 27.8 & Diatom \\
\hline Skeletonema costatum & 115600 & 484800 & $1.17 \mathrm{E}+07$ & 21.5 & Diatom \\
\hline $\begin{array}{l}\text { Pseudo-nitzschia delicatissima } \\
\text { complex }\end{array}$ & 23370 & 91600 & $2.36 \mathrm{E}+06$ & 4.3 & Diatom \\
\hline Thalassiosira spp. & 18560 & 72740 & $1.87 \mathrm{E}+06$ & 3.4 & Diatom \\
\hline Cochlodinium polykrikoides & 16230 & 93250 & $1.64 \mathrm{E}+06$ & 3.0 & Dinoflagellate \\
\hline Chaetoceros debilis & 9565 & 37408 & 966081 & 1.8 & Diatom \\
\hline Cerataulina pelagica & 7759 & 60500 & 783683 & 1.4 & Diatom \\
\hline Lauderia annulata & 4312 & 20269 & 435524 & 0.8 & Diatom \\
\hline Cylindrotheca closterium & 3371 & 6629 & 340510 & 0.6 & Diatom \\
\hline Bacteriastrum spp. & 2918 & 13678 & 294695 & 0.5 & Diatom \\
\hline Prorocentrum triestinum & 2755 & 21507 & 278293 & 0.5 & Dinoflagellate \\
\hline Pseudo-nitzschia seriata complex & 2195 & 6712 & 221675 & 0.4 & Diatom \\
\hline Prorocentrum micans & 1998 & 7368 & 201776 & 0.4 & Dinoflagellate \\
\hline Asterionella glacialis & 1730 & 9570 & 174731 & 0.3 & Diatom \\
\hline Prorocentrum gracile & 1452 & 3458 & 146675 & 0.3 & Dinoflagellate \\
\hline Chaetoceros van heurckii & 1291 & 8136 & 130396 & 0.2 & Diatom \\
\hline Alexandrium spp. & 1194 & 3613 & 120600 & 0.2 & Dinoflagellate \\
\hline Dictyocha spp. & 1095 & 8055 & 110639 & 0.2 & Silicoflagellate \\
\hline Chaetoceros radicans & 1033 & 8022 & 104317 & 0.2 & Diatom \\
\hline Heterosigma spp. & 904 & 6805 & 91277 & 0.2 & Dinoflagellate \\
\hline Gonylaulax spp. & 808 & 3620 & 81611 & 0.2 & Dinoflagellate \\
\hline Chaetoceros socialis & 800 & 7073 & 80846 & 0.1 & Diatom \\
\hline Navicula spp. & 776 & 3486 & 78408 & 0.1 & Diatom \\
\hline Scrippsiella trochoidea & 770 & 2677 & 77755 & 0.1 & Dinoflagellate \\
\hline Gunardia delicatula & 697 & 3777 & 70414 & 0.1 & Diatom \\
\hline Leptocylindrus minimus & 671 & 5792 & 67806 & 0.1 & Diatom \\
\hline Chaetoceros teres & 491 & 4018 & 49551 & 0.1 & Diatom \\
\hline Eucampia zodiacus & 468 & 2413 & 47284 & 0.1 & Diatom \\
\hline Thalassiosira nordenskioeldii & 465 & 4671 & 46943 & 0.1 & Diatom \\
\hline Dinophysis acuminata & 420 & 1259 & 42463 & 0.1 & Dinoflagellate \\
\hline Thalassionema spp. & 417 & 1916 & 42068 & 0.1 & Diatom \\
\hline Detonula pumila & 413 & 4152 & 41727 & 0.1 & Diatom \\
\hline Akashiwo sanguinea & 413 & 1940 & 41669 & 0.1 & Dinoflagellate \\
\hline Ceratium furca & 348 & 1158 & 35179 & 0.1 & Dinoflagellate \\
\hline
\end{tabular}




\begin{tabular}{|c|c|c|c|c|c|}
\hline Name & $\begin{array}{c}\text { Mean } \\
\text { (Cells/L) }\end{array}$ & Stand.Dev. & $\begin{array}{c}\text { Sum } \\
\text { (Cells/L) }\end{array}$ & $\begin{array}{l}\% \text { of } \\
\text { total }\end{array}$ & Group \\
\hline Leptocylindrus spp. & 261 & 2626 & 26389 & 0.0 & Diatom \\
\hline Protoperidinium excentricum & 232 & 1335 & 23472 & 0.0 & Dinoflagellate \\
\hline Bacteriastrum delicatulum & 232 & 2335 & 23471 & 0.0 & Diatom \\
\hline Alexandrium catanella & 207 & 1636 & 20864 & 0.0 & Dinoflagellate \\
\hline Thalassionema nitzschioides & 184 & 1196 & 18596 & 0.0 & Diatom \\
\hline Guinardia striata & 129 & 772 & 13040 & 0.0 & Diatom \\
\hline Oxyphysis oxytoxoides & 120 & 601 & 12076 & 0.0 & Dinoflagellate \\
\hline Nitzschia spp. & 118 & 648 & 11906 & 0.0 & Diatom \\
\hline Minuscula bipes & 108 & 866 & 10941 & 0.0 & Dinoflagellate \\
\hline Dinophysis fortii & 107 & 644 & 10772 & 0.0 & Dinoflagellate \\
\hline Chaetoceros similis & 103 & 1038 & 10432 & 0.0 & Diatom \\
\hline Cocconies spp. & 103 & 477 & 10432 & 0.0 & Diatom \\
\hline Fragilariopsis spp. & 103 & 511 & 10432 & 0.0 & Diatom \\
\hline Pseudo-nitzschia spp. & 83 & 474 & 8334 & 0.0 & Diatom \\
\hline Dinophysis rotundata & 79 & 586 & 7994 & 0.0 & Dinoflagellate \\
\hline Stephanopyxis palmeriana & 77 & 779 & 7824 & 0.0 & Diatom \\
\hline Polykrikos kofoidii & 77 & 578 & 7824 & 0.0 & Dinoflagellate \\
\hline Corethron spp. & 65 & 389 & 6605 & 0.0 & Diatom \\
\hline Dactyliosolen spp. & 55 & 553 & 5556 & 0.0 & Diatom \\
\hline Ceratium divericatum & 55 & 553 & 5556 & 0.0 & Dinoflagellate \\
\hline Ceratium lineatum & 55 & 389 & 5556 & 0.0 & Dinoflagellate \\
\hline Asteromphalus spp. & 52 & 365 & 5216 & 0.0 & Diatom \\
\hline Odontella spp. & 52 & 519 & 5216 & 0.0 & Diatom \\
\hline Protoperidinium conicum & 52 & 365 & 5216 & 0.0 & Dinoflagellate \\
\hline Protoperidinium pellucidum & 52 & 519 & 5216 & 0.0 & Dinoflagellate \\
\hline Ditylum brightwellii & 40 & 293 & 3997 & 0.0 & Diatom \\
\hline Pleurosigma normanii & 40 & 293 & 3997 & 0.0 & Diatom \\
\hline Lingulodinium polyedrum & 39 & 289 & 3912 & 0.0 & Dinoflagellate \\
\hline Prorocentrum spp. & 28 & 276 & 2778 & 0.0 & Dinoflagellate \\
\hline Protoceratium reticulatum & 28 & 276 & 2778 & 0.0 & Dinoflagellate \\
\hline Asteromphalus hepactis & 26 & 260 & 2608 & 0.0 & Diatom \\
\hline Alexandrium compressum & 26 & 260 & 2608 & 0.0 & Dinoflagellate \\
\hline Protoperidinium brevipes & 26 & 260 & 2608 & 0.0 & Dinoflagellate \\
\hline Protoperidinium leonis & 26 & 260 & 2608 & 0.0 & Dinoflagellate \\
\hline Protoperidinium oblongum & 26 & 260 & 2608 & 0.0 & Dinoflagellate \\
\hline Protoperidinium pentagonum & 26 & 260 & 2608 & 0.0 & Dinoflagellate \\
\hline Protoperidinium steinii & 26 & 260 & 2608 & 0.0 & Dinoflagellate \\
\hline Protoperidinium oceanicum & 13 & 130 & 1304 & 0.0 & Dinoflagellate \\
\hline
\end{tabular}

